\title{
Pemikiran Politik Nā'ilah Hāshim Ṣabrī dalam al-Mubșir li Nūr al-Qur'ān: Tumpuan Terhadap Pembebasan Bumi Palestin dan Masjid al-Aqsa
}

\author{
Maslina Muhammad \\ Universiti Malaya,74ismas@gmail.com \\ Mustaffa Abdullah \\ Universiti Malaya, mustaffa@um.edu.my \\ Monika@ Munirah Abd Razzak \\ Universiti Malaya,munirahar@um.edu.my
}

DOI: https://doi.org/10.22452/usuluddin.vol47no2.1

\begin{abstract}
Abstrak
Isu pembebasan bumi Palestin merupakan isu dan permasalahan umat Islam sejagat. Signifikan isu tersebut untuk diketengahkan kerana ia berkait rapat dengan bumi Palestin yang secara khusus menyentuh permasalahan sejarah dan kesucian Masjid al-Aqsa. Justeru, kajian berbentuk analisis kualitatif ini bertujuan menganalisis interpretasi pemikiran politik Nā'ilah Hāshim Șabrī menerusi karyanya al-Mubșir $l i$ Nūr al-Qur'ān, yang digarap daripada kefahaman ayat-ayat berkaitan permasalahan tersebut dalam al-Quran. Hasil analisis kajian menunjukkan, garapan pemikiran sosok tubuh tokoh pendakwah dan mufassirah ini konsisten menerapkan elemen pemikiran politik dengan mengangkat isu-isu signifikan dan kekinian yang berkaitan khusus dengan isu pembebasan bumi Palestin dan Masjid al-Aqsa.
\end{abstract}

Kata kunci: Nā'ilah Hāshim Șabrī, pemikiran politik, Zionisme, Palestin, Masjid al-Aqsa

\section{The Political Thought of Hāshim Șabrī in al-Mubșir li Nūr al-Qur'ān: a Focus on the Liberation of Palestine and al-Aqsa Mosque}

\section{Abstract}

The issue of Palestine liberation is a universal issue and concern for Muslims. The issue of Palestine liberation is a universal issue and concern for Muslims. The issue is worth pointing out as it is inextricably linked to the Palestinian land that specifically touches on the history and sanctity of the al-Aqsa Mosque. Therefore, the qualitative analysis study aims to analyze the interpretation of the political thought of Nä'ilah Hāshim Sabrī through his work al-Mubșir li Nūr al-Qur'ān, which is based on the understanding of verses related to these issues in the Quran. The finding of study show that the thought process of the body of the preacher and the mufassirah is consistent with the political element 
by raising significant and specific issues related to the issue of the liberation of Palestine and the al-Aqsa Mosque.

Keywords: Nā'ilah Hāshim Sabrī, political thought, Zionism, Palestine, al-Aqsa Mosque

\section{Pendahuluan}

Sejarah bumi Palestin adalah satu sejarah yang berada di tempat teratas di dalam rangkaian dan rentetan kezaliman dan pencerobohan dalam sejarah dunia moden. Isu dan permasalahan berkaitan pembebasan bumi Palestin dan Masjid al-Aqsa merupakan isu umat Islam sejagat. Permasalahan penting ini, disentuh secara khusus oleh Nā'ilah Hāshim Sabrīe satu nama personaliti dakwah yang mempunyai sumbangan besar dalam bidang tafsir, menerusi hasil karya ulungnya al-Mubșir li Nür alQur'ān.

Keperibadian Nā'ilah sebagai seorang pendakwah dan mufassirah yang menghadami isu dan permasalahan umat, adalah hasil dari cernaan rutin kehidupan beliau dalam suasana persekitaran dan pengalaman hidup di tanah airnya sendiri. Bumi Palestin yang masih terjajah dan dijarah, telah mematangkan diri beliau dan membentuk garapan pemikiran yang terhasil daripada penjanaan dan adunan dari dua elemen penting iaitu pengalaman dan keilmuan, secara tidak lansungctelah memberi impak yang besar terhadap pembentukan peribadi dan pemikiran Nā'ilah. Justeru, secara jelas dapat dilihat bahawa bentuk pemikiran dan lontaran idea dalam karya agungnya al-Mubșir li Nür al-Qur'ān serta karya-karyanya yang lain, adalah terhasil dari cetusan pemikiran dan terjemahan keilmuan beliau yang bersifat realistik dan respons kepada permasalahan ummah yang dihadapinya.

Menerusi karya tafsir al-Mubșir li Nūr al-Qurā'n, tergambar jelas bahawa garapan pemikiran politik Nā'ilah terbentuk hasil daripada penjanaan idea dan pemikiran politik yang bersumberkan kepada al-Quran yang menjadi pemangkin pemikirannya. Secara tuntas, transmisi idea dan cetusan pemikiran beliau secara jelas dapat disingkap menerusi metodologi pentafsirannya yang ringkas, ${ }^{1}$ namun padat dengan hujah dan dalil yang konkrit,

1 Dapatan kajian yang diperolehi menunjukkan, sebahagian besar daripada persoalan dan permasalahan yang dikemukakan secara ringkas dalam al- 
sehingga mampu menyingkap aliran pemikiran politik beliau secara konsisten.

\section{Pemikiran Politik}

Perbahasan pemikiran politik Islam merupakan antara pokok perbincangan yang sering menarik minat kebanyakan para sarjana Islam untuk memperluaskan skop perbincangan dalam karya-karya penulisan mereka termasuk karya dalam bidang tafsir. Di antara perkara pokok yang dibincangkan dalam perbahasan politik Islam termasuk konsep shürā, ${ }^{2}$ prinsip al-amr bi al-ma 'rūf wa al-nahy 'an al-munkar, ${ }^{3}$ ahl al-hal wa al-'aqd ${ }^{4}$ dan dasar imāmah ${ }^{5}$.

Menurut Nā'ilah Hāshim Șabrī, perkaitan antara politik dengan agama merupakan satu perkaitan yang amat penting. Ini kerana, Islam berfungsi sebagai suatu sistem kehidupan bagi memandu manusia dalam semua urusan yang berkait dengan bidang ekonomi, sosio budaya kemasyarakatan, sistem politik dan

Mubșir li Nūr al-Qur'ān, telah dibahaskan secara panjang lebar dan lebih meluas oleh Nā'ilah dalam dua buah karya beliau yang lain iaitu dalam $F \bar{\imath}$ Zilāl Āyah dan Khawātir Nadiyyah wa Afkār Maqdasiyyah. Hal sedemikian merupakan antara bentuk dan metode pentafsiran yang konsisten diaplikasikan oleh Nā'ilah dalam keseluruhan karya tafsir al-Mubșir li Nūr al-Qur'ān, dan ia diakui sendiri oleh Nā'ilah dalam muqqadimah tafsirnya bahawa antara tujuannya adalah bagi mengelakkan wujudnya unsur-unsur Isrā'ìliyyāt, mengurangi perbahasan khilaf antara mazhab serta mengenepikan perkaraperkara sampingan yang dilihat tidak begitu penting. Lihat Nā'ilah Hāshim Șabrī, al-Mubșir li Nūr al-Qur'ān, (al-Quds: Maṭba'ah al-Risālah alMaqdasiyyah, 1997) 1: 11.

2 Al-Qurțubī ( w.671H), menjelaskan pandangan Ibn 'Ațiyyah tentang syura; "Dan shürā merupakan salah satu kaedah syarak, dan kekekuatan hukum, justeru barangsiapa yang tidak berunding dengan ahli ilmu dan agama, maka wajib disingkirkan, tanpa khilaf dalam hal ini. Lihat Abū 'Abd Allah Muḥammad bin Abī Bakr bin Farḥ al-Anșārī al-Khazrajī al-Andalūsī alQurțubī, Al-Jāmi ' li Aḥkām al-Qur'ān (Amman: Dār al-Fikr, 1993), 4:249.

3 Perbincangan tentang kewajipan melaksanakan al-amr bi al-ma 'rūf wa alnahy 'an al-munkar, begitu banyak dibahaskan dalam karya-karya berkaitan politik Islam dan perundangan. Ia dikupas secara terperinci oleh Qāḍ̄ Abū Yūsuf Ya'qūb dalam kitabnya al-Kharaj.

4 Iaitu pihak yang memperolehi mandat dan pengiktirafan dalam menetapkan kuasa untuk mengikat dan merombak sesuatu ketetapan.

5 Persoalan imāmah (kepimpinan) antara kupasan yang diperincikan oleh alGhazālī dalam kitabnya al-Iqtiṣād fì al-I'tiqād. 
perundangan, pensyari'atan undang-undang, serta orientasi pendidikan dan intelektual. ${ }^{6}$

Pemikiran politik Nā'ilah dapat dilihat menerusi tafsiran ayatayat politik dalam tafsirnya al-Mubșir li Nūr al-Qur'ān, disertai dengan perbincangan secara berasingan dalam karyanya yang lain seperti dalam Khawātị Nadiyyah wa Afkār Maqdasiyyah dan Fī Ziläl Áyah. Walau bagaimanapun, hanya aspek daripada pemikiran politik, yang diberi tumpuan dalam kajian bab ini iaitu persoalan tentang kepentingan membebaskan bumi Palestin dan Masjid alAqsa.

\section{Kepentingan Membebaskan Bumi Palestin dan Masjid al- Aqsa}

Cetusan pemikiran politik Nā'ilah, menzahirkan refleksi terhadap pengalaman peribadinya yang terkesan dengan pergolakan situasi politik di tanah airnya, Palestin. Ini kerana, beliau lahir dan membesar dalam situasi dan lingkungan kehidupan yang sangat mencabar dan penuh tribulasi. Semenjak kecil, beliau merasai denyut nadi kesukaran hidup yang penuh jerih di bawah penjajahan tentera Zionis Yahudi yang terus-menerus menindas dan melakukan kekejaman di luar batas kemanusiaan terhadap rakyat Palestin.

Justeru pola pemikiran politik beliau dapat dilihat secara jelas terutamanya menerusi tafsiran ayat-ayat yang berkaitan dengan sejarah Bani Isra'il dan bumi Palestin. Percambahan pemikiran inilah yang banyak mendominasi tafsiran beliau dalam karyanya al-Mubșir li Nūr al-Qur'ān serta karya-karya beliau yang lain.

Dalam usaha untuk membawa isu Palestin ke mata dunia, Nā'ilah telah memanfaatkan segala kemudahan media massa yang ada untuk membawa keluar suara rakyat Palestin keseluruh ceruk dunia. Maka terhasilnya puluhan tulisan beliau dalam bentuk buku-buku, makalah dan risalah yang tersiar di dalam akhbarakhbar dan majalah tempatan, diikuti dengan karya-karyanya seperti al-Mubșir li Nūr al-Qur'ān, Palesțīniyyah Sa'abqua, Khawātir Nadiyyah wa Afkār Maqdasiyyah, Hādhihī Ummatī, Wamdah fì Zulām dan Fì Zilāl Āyah. Tidak sekadar itu, beliau

6 Nā'ilah Hāshim Șabrī, Khawātị Nadiyyah wa Afkār Maqdasiyyah (Amman: Dār al-Nafā'is, 2014), 373. 
turut membawa suara masyarakat Islam Palestin dengan memanfaatkan sepenuhnya setiap peluang yang diberikan untuk bersiaran menerusi stesen radio dan televisyen tempatan atau di luar negara.

Sehingga ke hari ini ${ }^{7}$, Nā'ilah masih istiqamah dengan misi dakwahnya dalam siri penyampaian kuliah-kuliah agama, forum dan seminar antarabangsa serta siri kembara jelajah dunia membawa isu Palestin. Beliau secara tegas menyatakan bahawa beliau akan terus berjihad menggunakan lidah, pena dan segala kekuatan dan keupayaannya untuk melawan rejim Zionis Yahudi sehingga Palestin dibebaskan atau dengan penamatan akhir hayatnya. ${ }^{8}$

Nā'ilah Hāshim Șabrī berpendirian tegas bahawa isu Palestin merupakan isu umat Islam sejagat, maka isu tersebut perlu diletakkan sebagai permasalahan besar umat Islam. Ini kerana, bumi Palestin berhubung kait secara khusus dengan sejarah dan kesucian Masjid al-Aqsa. ${ }^{9}$ Bahkan yang paling utama dalam persoalan Palestin juga adalah, ia termasuk dalam isu tuntutan istirdād al-huqūq al-maslübah (mengembalikan hak-hak yang dirampas). ${ }^{10}$ Justeru, isu bumi Palestin ini wajar dihalusi, dikaji dan dianalisis dari dua aspek utama,iaitu dari fakta sejarah dan penjelasan dari nas al-Quran dan hadith. ${ }^{11}$ Hubungkait antara fakta sejarah $^{12}$ dengan dalil dan nas yang sahih adalah asas yang

7 Dalam kembara ilmu dan dakwah, Nā'ilah telah mengadakan puluhan lawatan ke seluruh benua Eropah dan Asia. Di benua Asia Tenggara, Malaysia merupakan antara negara yang paling kerap dilawati beliau, iaitu melebihi lima kali lawatan. Lawatan kali terakhir beliau ialah pada tanggal 15-25 November 2018 dalam siri jelajah Malaysia bersama suaminya, bagi memberi penerangan tentang hal ehwal semasa bumi Palestin.

8 Nā'ilah Hāshim Șabrī (Pengarang al-Mubșir li Nūr al-Qur'ān), dalam temubual dengan pengkaji, di Bilik 2612, PNB Perdana Hotel \& Suites, 10 Jalan Binjai, 50450 Kuala Lumpur, 2 November 2017, jam 2.30 petang.

9 Nā'ilah Hāshim Șabrī, al-Mubșir li Nūr al-Qur'ān, 1: juz 2, 183-185.

10 Nā'ilah Hāshim Șabrī, "Istirdād al-Huqūq al-Maslūbah" dalam Khawātị Nadiyyah wa Afkār Maqdasiyyah, 358-359.

11 Nā'ilah Hāshim Sabrī, dalam temubual dengan pengkaji, di bilik 803 Hotel Impiana, Ipoh, Perak pada 11 Februari 2018, 2.45 petang.

12 Berdasarkan kajian yang dibuat oleh Mohd Roslan Mohd Nor, dinyatakan bahawa rancangan untuk menguasai Palestin oleh rejim Zionis Yahudi telah bermula sejak 1986 lagi. Sejarahnya begitu berharga dan mempunyai cerita yang panjang. Idea asalnya telah dikemukan oleh Theodor Herzl yang telah 
menjadi tunjang kekuatan dalam perjuangan membebaskan Palestin dari cengkaman penjajahan serta mengembalikan hak umat Islam yang telah dirampas rejim Zionis Yahudi.

\section{Sejarah Pemilikan Bumi Palestin}

Bumi Palestin mempunyai catatan sejarah dan keistimewaanya yang tersendiri. Bagi Palestin, ia adalah tempat yang menjadi tumpuan bagi tiga agama samawi iaitu Islam, Kristian ${ }^{13}$ dan Yahudi. ${ }^{14}$ Hakikatnya, bumi Palestin yang terkait dengan kesucian kota Baitul Maqdis dan Masjid al-Aqsa adalah berdasarkan kepada realiti sejarah keagamaannya sebagai tanah suci yang diberkati. Ia juga ada sejarahnya tersendiri yang berkait dengan sejarah dakwah para Rasul, sama ada yang berasal dari Palestin mahupun yang diperintahkan oleh Allah SWT untuk berhijrah ke bumi Palestin bagi kelansungan kerja-kerja dakwah.

Sehingga ke saat ini, sejarah bumi Palestin adalah menduduki tangga teratas di dalam rangkaian dan rentetan kezaliman dan

membuat dasar-dasar umum pembentukan rejim Zionis agar terlahir sebuah negara khusus untuk orang-orang Yahudi. Setelah kejatuhan Empayar Uthmaniyah semasa Perang Dunia Pertama, pihak British telah cuba mengaturkan negara Yahudi di bumi Palestin bagi mengekalkan dominasi mereka di walayah strategik Timur Tengah dan negara-negara Islam. Lihat Mohd Roslan Mohd Nor, "Perancangan Zionis ke Arah Pembentukan Negara Israel" Jurnal Usuluddin 30 (Julai-Disember 2009), 234.

13 Menurut kepercayaan Kristian, kota Baitul Maqdis itu dianggap sebagai tempat semangat dan pensaliban. Nur Maisarah Abdullah, "Kepercayaan Yahudi Terhadap Konsep Bumi yang Dijanjikan" (makalah, Seminar Jabatan Sejarah dan Tamadun Islam, Akademi pengajian Islam Universiti Malaya, 2005).

14 Istilah Yahudi menurut perspektif Barat merujuk kepada satu entiti yang bersepadu meliputi elemen-elemen etnik,bangsa dan agama. Dalam The Oxford English Dictionary, Jews atau juga dikenali dengan nama kaum Hebrew, berasal dari sebutan bahasa Greek, 'Ioudios' yang dikembangkan daripada perkataan 'Yahudah' di dalam Bahasa Hebrew.Ia merujuk kepada asal-usul bangsa Yahudi atau Hebrew yang berasal dari nama 'Judah', putera keempat kepada Jacob dan Leah. Lihat Mohamad Fauzi Zakaria, 'Bumi yang Dijanjikan' Menurut Perspektif Yahudi dan Kaitannya dengan Penuduhan Negara Israel (1948): Analisis dari Sudut Perspektif Islam" (Tesis kedoktoran, Jabatan Akidah dan Pemikiran Islam, Akademi Pengajian Islam, Universiti Malaya, 2011), 48. Mohd Roslan Mohd Nor, "Konflik Israel -Palestin dari Aspek Sejarah Moden dan Langkah Pembebasan Dari Cengkaman Zionis", Jurnal Al-Tamaddun 5 (2010), 74. 
pencerobohan dalam sejarah dunia moden. ${ }^{15}$ Konflik yang berlaku di Palestin di antara orang Arab dan Yahudi telah berlarutan sejak sekian lama, terutamanya setelah pengisytiharan penubuhan rasmi negara Israel pada 15 Mei $1948^{16}$ dan ia berlarutan hampir tujuh dekad sehingga ke hari ini.

Dalam Islam, konsepsi mengenai bumi Palestin adalah berbeza dengan dakwaan dan perspektif orang-orang Yahudi. Perbezaan ini adalah bertitik tolak dari sumber rujukan utama kedua-duanya. Asas dakwaan Yahudi yang didakwa merujuk kepada kenyataan di dalam siri-siri covenant (perjanjian) di dalam kitab mereka Jewish Bible yang mengutarakan konsep "bumi yang dijanjikan" kepada bangsa Yahudi. Walau bagaimanapun, Islam mempunyai hujah-hujah dan dalilnya dalam mempersoalkan asas dakwaan Yahudi tersebut, berasaskan penjelasan hal yang sama menurut al-Quran. ${ }^{17}$

Atas asas ini, Nā'ilah menegaskan bahawa sejarah pemilikan bumi Palestin perlu dilihat berdasarkan penegasan beberapa ayat al-Quran yang merujuk bumi Syam (Palestin) sebagai bumi Allah SWT yang berkat, ${ }^{18}$ sekaligus menjadi hujah bagi menolak dakwaan golongan Yahudi yang mendakwa Baitul Maqdis sebagai

15 Sejarah penjajahan Palestin oleh Zionis Yahudi, merupakan perbincangan yang cukup luas. Dalam kajian ini, tumpuan kajian adalah terhadap pemikiran politik Nā'ilah Hāshim Șabrī dalam tafsir beliau yang menyentuh isu Palestin secara khusus ketika perbincangan dan pentafsiran ayat-ayat al-Quran yang berkaitan.

16 Kesan dari pengisytiharan penubuhan Israel tersebut, maka bermula lah perang Perang Arab-Israel 1948 , dikenali juga sebagai Perang Kemerdekaan Israel. Ia adalah perang yang pertama di dalam satu siri peperangan antara negara Israel dan negara jiran Arab dalam konflik Arab-Israel. Bagi orang-orang Yahudi Israel, peperangan ini menandakan kejayaan penubuhan negara Israel, tetapi bagi orang-orang Arab Palestin, ia menandakan permulaan bagi peristiwaperistiwa yang dirujuk sebagai "Al-Nakbah" (النكبة) iaitu malapetaka.

Gambaran malapetaka tersebut bermula dengan pengusiran keluar beratusratus ribu penduduk Palestin tempatan dari negara Israel yang baru dibentuk, dan kemudiannya pelarangan pihak Israel terhadap warga Palestin untuk kembali ke kampung halaman mereka. Lihat "Perang Arab-Israel 1948," laman sesawang Wikipedia Ensiklopedia Bebas, dikemaskini 6 April 2015, dicapai 3 Mac 2018, https://ms.wiki pedia.org/wiki /Perisytiharan_penubuhan

17 Ibid., 5. negara_Israel.

18 Nā'ilah, al-Mubșir li Nūr al-Qur'ān, 7: juz 17, 45-46. 
"bumi yang dijanjikan"19 untuk mereka, sedangkan dakwaandakwaan tersebut masih menjadi sebuah pertikaian, lantaran perkaitan yang tidak jelas antara dakwaan Yahudi tersebut dengan sejarah penaklukan golongan Yahudi ke atas bumi Palestin. ${ }^{20}$

Melalui beberapa tafsiran ayat-ayat al-Quran yang disentuh oleh Nā'ilah, yang secara khusus dan jelas merujuk kepada beberapa kalimah "al- "ard" "21 sebagai negeri Syam, yang termasuk di dalamnya ialah bumi Palestin, iaitu bumi Allah SWT yang diberkati. Antaranya firman Allah SWT:

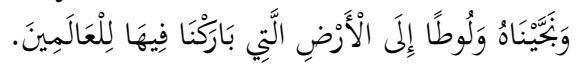

Al-Anbiyā' 21:71

Terjemahan: "Dan Kami selamatkannya (Ibrāhīm) dan Lut ke sebuah negeri yang Kami telah berkatinya, untuk sekalian manusia".

Dalam pentafsiran ayat tersebut, Nā'ilah menjelaskan bahawa Allah telah menyelamatkan Nabi Ibrahim a.s bersama anak saudaranya Lut a.s dari ancaman keras kaumnya dengan memerintahkan Ibrahim a.s meninggalkan bumi Iraq dan berhijrah ke negeri Syam, sebuah negeri yang berkat. Dimaksudkan dengan bumi yang diberkati, kerana ia penuh dengan limpahan kebaikan dan keberkatan, di dalamnya terdapat pohon-pohon yang subur dan buah-buahan, dan ia juga adalah bumi para Anbiya'. ${ }^{22}$

Ayat 71 surah al-Anbiyā ini telah ditafsirkan secara meluas dalam kalangan mufassirīn sejak dahulu. Antaranya ialah Ibn Jārīr al-Ṭabarī, yang menjelaskan berdasarkan satu riwayat daripada Ibn

19 Menurut kaum Yahudi, mereka telah dijanjikan dengan sebuah negeri kediaman di bumi Kana'an ( Land of Canaan). Pegangan mereka ini adalah berdasarkan kepada covenant (perjanjian) dengan Tuhan sebagaimana yang tercatat di dalam kitab suci mereka Jewish Bible. Covenant yang mengutarakan persoalan "bumi yang dijanjikan" (A Promised Land) kepada kaum bangsa yang juga terkenal sebagai Bani Israel ini merupakan satu konsep yang berasaskan kepada Bible (Biblical Concept). Mohamad Fauzi Zakaria, "Bumi Yang Dijanjikan" Menurut Perspektif Yahudi dan Kaitannya dengan Penubuhan Negara Israel (1948): Analisis dari Sudut Perspektif Islam", 1.

20 Muhammad "Ammārah, "Al-Quds Bayna al-Yahūdiyyah wa al-Islām (Kaherah: Dār Nahḍah Miṣr li al-Ṭibā'ah wa al-Nashr wa al-Tawzī‘, 1999), 24-29.

21 Nā'ilah, al-Mubșir li Nūr al-Qur'ān, 7: juz 17, 45.

22 Ibid. 
Isḥāq, bahawa Ibrahim a.s keluar berhijrah ke sebuah negeri yang diperintahkan Tuhannya bersama isterinya Sarah, dan anak saudaranya Lut bagi berdakwah mengajak manusia beribadah kepada Allah, dari Kaldan di selatan Iraq, menuju ke bumi Syam (termasuk di dalamnya negara Palestin), dan seterusnya ke Mesir sebelum kembali semula ke Syam dan menetap di Bi'r al-Sab 'ah di selatan Palestin. ${ }^{23}$

Begitu juga dalam tafsiran Ibn Kathīr, ${ }^{24}$ yang turut menyatakan hal yang sama seperti pentafsiran yang dibuat oleh alTabarī, yang memperincikan lagi peristiwa tersebut dalam karyanya Qașaș al-Anbiyā'. Menurut Ibn Kathīr, jejak perjalanan Ibrāhīm AS yang berhijrah dari Kaldan, Iraq iaitu di sepanjang jalur Sungai Furat menuju ke bumi Kan'an (Palestin), secara tidak lansung mengaitkannya dengan bumi hijrah berkat, yang terletak padanya Baitul Maqdis. ${ }^{25}$ Inilah antara kesepakatan para mufassirīn, bahawa itulah asas perjalanan hijrah Ibrāhīm AS dari Iraq ke Syam, iaitu semata-mata mentaati perintah Allah SWT dan perjalanan melaksanakan tanggungjawab dakwah, bercanggah dengan konsep yang ditekankan dalam Jewish Bible yang menekankan konsep berhijrah ke "bumi yang dijanjikan" untuk bangsa Yahudi. ${ }^{26}$

Manakala persoalan tentang zuriat keturunan Ibrahim a.s yang bakal mewarisi bumi Kan'an, dapat diperhatikan dalam tafsiran ayat seterusnya iaitu pada ayat 72 surah al-Anbiyā', ketika Allah SWT menyampaikan berita gembira kepada Ibrahim a.s, bahawa Allah SWT akan mengurniakan kepada Ibrahim a.s zuriat keturunan, iaitu Isḥāq dan Ya'qūb, sebagaimana firmanNya:

${ }^{23}$ Lihat Abū Ja'far Muhammad bin Jārīr bin Yazīd al-Ṭabarī, Jāmi ‘ al-Bayān 'an Ta'wīl Āyi al-Qur'ān (Beirut: Dār al-Fikr, 1988).

24 'Ismā'īl bin 'Amr bin Kathīr, Tafsīr al-Qur'ān al-'Azīm (Riyadh: Dār alȚaybah li al-Nashr wa al-Tawzī, 2009), 2: 61.

${ }^{25}$ Ismā'îl ibn 'Umar ibn Kathīr, Qașaș al-Anbiyā', taḥqīq Qāsim al-Rifā'ī (t.tp: Sharīkah Dār al-Arqām bin Abī al-Arqām, t.t.), 113-114.

${ }^{26}$ Mohamad Fauzi Zakaria, "Bumi Yang Dijanjikan" Menurut Perspektif Yahudi dan Kaitannya dengan Penuduhan Negara Israel (1948): Analisis dari Sudut Perspektif Islam", 177. 


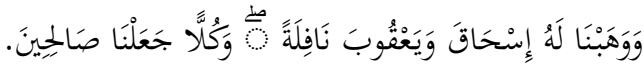

Al-Anbiyā' 21:72

Terjemahan: "Dan Kami telah mengurniakan kepadanya (Ibrāhīm), Isḥāq dan Ya'qūb, sebagai suatu anugerah (dari Kami), dan masing-masing Kami jadikan orang-orang yang soleh."

Menerusi tafsiran ayat tersebut, Nā'ilah menjelaskan bahawa Allah SWT mengurniakan kepada Ibrahim a.s seorang anak iaitu Isḥāq, setelah sekian lama Ibrāhīm AS berdoa kepada Tuhannya agar dikurniakan zuriat. Seterusnya dikurniakan lagi zuriat keturunannya dari Isḥāq dan puteranya Ya'qub AS, kemudian dikurniakan juga kepadanya seorang anak iaitu Ismail, sebagai satu anugerah dan kelebihan dari kurniaan Allah SWT kepada Ibrahim a.s. Seterusnya Allah SWT menjadikan kedua-duanya, iaitu Isḥāq dan Ya'qub sebagai orang-orang soleh, yang juga bakal dilantik sebagai Nabi. ${ }^{27}$

Hal ini turut ditegaskan oleh Nā'ilah berdasarkan pandangan Ibn Kathīr yang menyebut bahawa, penganugerahan anak-anak dan zuriat yang soleh tersebut itulah merupakan di antara bumi yang berkat, kerana sejak beberapa lama sebelumnya sewaktu berada di negeri asalnya Iraq, Ibrahim a.s tidak memperolehi zuriat. $^{28}$ Seterusnya dijelaskan bahawa, Ismail a.s adalah bapa kepada bangsa Arab, manakala Isḥāq AS dan puteranya Ya'qūb a.s adalah bapa kepada bangsa Yahudi. Melalui Ishaq dan Ya'qub ini, terbinanya kesinambungan para Nabi dan Rasul dalam kalangan Bani Israil sehingga berakhir kepada 'Isa a.s, manakala dari zuriat Ismail a.s lahirnya Muhammad SAW, yang menjadi penutup risalah kenabian. ${ }^{29}$

Dari sudut pandangan Islam, bumi Palestin yang terletak padanya kota suci Baitul Maqdis atau al-Quds, adalah bumi berkat, lantaran ia telah didiami oleh para Anbiya' dari kalangan Bani Israel. Islam merujuk istilah Bani Israil kepada keseluruhan kaum bangsa dari keturunan Ya'qub a.s yang digelar "Israil", generasi kedua dari zuriat Ibrahim a.s dari puteranya Ishaq a.s

\footnotetext{
7 Nā'ilah, al-Mubșir li Nūr al-Qur'ān, 7: juz 17, 46.

28 Ibn Kathīr, Qașaș al-Anbiyā', 113.

${ }^{29}$ Ibn Kathīr, Tafsìr al-Qur'ān al- 'Az̄ìm, 3:
} 
melalui isterinya Sarah. ${ }^{30}$ Manakala menurut Șalāḥ al-Khālidī, berdasarkan kepada keterangan- keterangan al-Quran dan tafsiran para mufassirin, istilah Bani Israil merujuk kepada makna umum termasuk para Nabi dan orang-orang soleh dari keturunan Ya'qub a.s (Israil). Bahkan al-Quran secara lebih khusus, merujuk istilah al-Yahüd kepada keturunan dari kaum dan bangsa yang memusuhi Rasulullah SAW serta mendedahkan tabiat buruk dan perancangan jahat orang-orang Yahudi terhadap Islam pada zamannya di Madinah. ${ }^{31}$

Walau bagaimanapun, realiti hari ini memperlihatkan bahawa golongan Yahudi tetap merasakan Palestin dan Jerusalem (Zion) adalah hak milik mutlak bangsa mereka untuk selama-lamanya seperti dijanjikan Tuhan menurut kitab suci mereka Jewish Bible. Pada zaman moden ini, golongan Yahudi diaspora ${ }^{32}$ telah menggerakkan daya usaha untuk kembali menempatkan bangsa mereka di sebuah "Negara Israel" yang berdaulat di Palestin sebagai "bumi yang dijanjikan" (The Promised Land) untuk mereka. ${ }^{33}$

Justeru, pentingnya dalam memahami perbezaan makna bagi dua istilah ini iaitu Bani Israil dan al-Yahūd, kerana walaupun keduanya saling berkaitan, namun perbezaan hakikat di antara keduanya memberikan impak yang besar dan signifikan dalam memahami dan menyelesaikan hakikat pertikaian dalam isu Palestin.

Bahkan bagi Nā'ilah, asas dakwaan golongan Yahudi yang bersandarkan kepada latar belakang keturunan semata-mata, tidak boleh diterima untuk dijadikan ukuran dan penilaian bagi dakwaan-dakwaan Yahudi bahawa mereka lebih berhak ke atas bumi Palestin. Nā'ilah turut menegaskan, sewajarnya penentuan

${ }^{30}$ Sa'ūd bin 'Abd al-'Azīz al-Khalaf, Dirāsāt fì al-Adyān al-Yahūdiyyah wa alNașrāniyyah (Riyadh: Aḍ̂ā’ al-Salaf, 2006), 36.

31 Șalāḥ 'Abd al-Fattāḥ al-Khālidī, Al-Syakhsiyyāt al-Yahūdiyyah min Khilāl alQur'ān (Damascus: Dār al-Qalam, t.t.), 39-40.

32 Istilah diaspora merujuk kepada kelompok manusia yang pada asalnya tergolong dalam budaya yang sama yang telah tersebar ke merata-rata tempat lain.

${ }^{33}$ Mohamad Fauzi Zakaria, "Bumi Yang Dijanjikan" Menurut Perspektif Yahudi dan Kaitannya dengan Penuduhan Negara Israel (1948): Analisis dari Sudut Perspektif Islam", 17. 
bagi persoalan yang mengaitkan golongan dari keturunan Nabi Ibrāhīm AS dengan hak ke atas bumi Palestin, perlu dilihat juga berdasarkan penegasan Allah SWT sendiri terhadap persoalan tauhid serta risalah kenabian Nabi Ibrahim a.s, ${ }^{34}$ sepertimana firman-Nya dalam ayat 67 surah Āli 'Imrān:

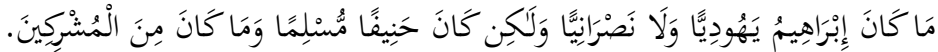

$$
\begin{aligned}
& \text { Āli 'Imrān 3:67 }
\end{aligned}
$$

Terjemahan: "Bukanlah Nabi Ibrahim itu seorang Yahudi dan bukan juga Nasrani, akan tetapi dia adalah seorang yang tetap di atas dasar tauhid sebagai seorang Muslim (yang taat dan berserah bulat-bulat kepada Allah) dan dia bukan sekali-kali dari kalangan orang musyrik".

Pendapat Nā'ilah memperkukuhkan lagi pandangan beliau dengan memetik tafsiran Ibn 'Abbās ketika memperincikan sabab al-nuzūl bagi ayat 68 surah Āli 'Imrān. Ia menjelaskan bahawa orang yang paling berhak untuk dinasabkan dengan keturunan Nabi Ibrahim a.s ialah dari kalangan orang Islam. ${ }^{35}$ Hal ini diperjelaskan lagi berdasarkan penegasan Allah SWT dalam ayat yang lain:

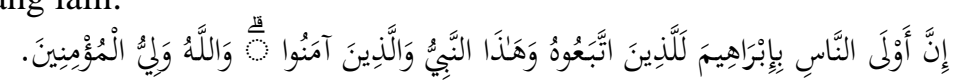

Āli ‘Imrān 3:68

Terjemahan: "Sesungguhnya orang yang paling hampir sekali dengan Ibrāhīm (dan berhak mewarisi agamanya) adalah orang yang mengikutinya dan juga Nabi ini (Muhammad), serta orang- orang yang beriman. Dan (ingatlah) Allah adalah pelindung dan penolong bagi sekalian orang-orang beriman".

Berdasarkan ayat ini, Nā'ilah merumuskan bahawa bumi Palestin adalah milik keturunan Nabi Ibrahim a.s. Keturunan tersebut adalah dalam kalangan kaum Muslimin yang mengukuti ajaran Nabi Ibrahim a.s. ${ }^{36}$ Tambahan lagi, terdapat dalam beberapa nas al-Quran selainnya, serta Hadith Nabawi yang sahih, begitu jelas menunjukkan bahawa hak bumi Palestin adalah berpaksi kepada Islam. Ini adalah kerana, para nabi yang berhijrah ke

${ }^{34}$ Nā'ilah Hāshim Șabrī, al-Mubșir li Nūr al-Qur'ān, 2: juz 3, 252-253.

${ }^{35}$ Ibid., 254.

${ }^{36}$ Lihat juga pada tafsiran ayat al-Quran yang lain dalam surah al-Naḥl: 123, alNisā': 125. 
Palestin, atau yang lahir dan mengimarahkan Baitul Maqdis terdiri daripada orang-orang Islam.

Hal sedemikian dapat difahami dengan lebih jelas berdasarkan kepada pendapat Șalāḥ al-Khālidī, yang menyatakan bahawa rumusan yang boleh disimpulkan menerusi kenyataan beliau yang menyatakan bahawa apabila Allah SWT mengutuskan baginda Rasullah SAW kepada umat manusia, itulah pewarisnya yang terakhir dari warisan agama Ibrahim s.a dan para Nabi dari zuriatnya. Begitu juga umat Muhammad SAW seluruhnya, tanpa mengira mengira dari zuriat sesiapa, adalah pewaris kepada agama para Nabi ini. ${ }^{37} \mathrm{Hal}$ yang sedemikian diperkukuhkan lagi menerusi tafsiran Nā'ilah Hāshim Șabrī pada ayat 123 dalam surah al-Naḥl sebagaimana firman Allah SWT:

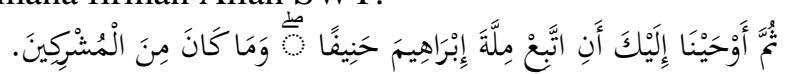

Al-Nahl 16:123

Terjemahan: "Kemudian Kami wahyukan kepadamu (wahai Muhammad); hendaklah kamu mengikuti agama Ibrahim, yang berdiri teguh di atas jalan yang benar, dan tidaklah dia dalam kalangan orang-orang musyrik"

Justeru, perkaitan hubungan kaum Muslimin dari umat Muhammad SAW dengan Israil (Ya'qub a.s ) dan para Nabi dari zuriatnya adalah lebih utama dari sudut pewarisan agama, berbanding dengan konsepsi Bani Israel yang telah menyimpang jauh dari agama Allah SWT yang hakiki. Ini kerana, kaum Muslimin berpegang teguh kepada penjelasan Allah SWT di dalam al-Quran mengenai janji-janji pewarisan bumi ini kepada hamba-hamba-Nya. Diantaranya ialah janji Allah SWT kepada Dāwūd AS di dalam ayat 26 surah Șād, bahawa bumi ini seluruhnya milik Allah SWT dan ianya akan diwariskan kepada hamba-hamba-Nya yang soleh. Justeruatas dasar sedemikian, Islam menolak dakwaan Yahudi tentang persoalan hak warisan mereka ke atas bumi Palestin.

Persoalan seterusnya ialah yang berkaitan dengan persoalan "bumi yang dijanjikan". Orang Yahudi percaya bahawa mereka lebih berhak ke atas bumi Palestin, bersandarkan kepada kitab suci mereka Jewish Bible. Hakikatnya, persoalan tersebut telah

\footnotetext{
37 Șalāḥ al-Khālidī, Al-Syakhsiyyāt al-Yahūdiyyah min Khilāl al-Qur'ān, 39.
} 
dibahaskan oleh ramai dalam kalangan mufassirin ketika merujuk kepada frasa " tanah suci yang telah ditentukan Allah kepada kamu" pada tafsiran ayat 21 surah al-Mā'idah:

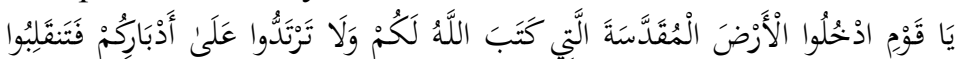

$$
\text { خَاسِرِينَ. }
$$

Al-Mā'idah 5:21

Terjemahan: "Wahai kaumku! Masuklah kamu ke Tanah Suci (Palestin),yang telah ditentukan Allah bagimu, dan janganlah kamu lari ke belakang (kerana takut kepada musuh), maka nescaya kamu akan menjadi orang yang rugi”.

Merujuk kepada ayat 21 surah al-Mā'idah ini, Nā'ilah dalam tafsirannya telah membawa pandangan yang hampir sama dengan kebanyakan para ulama dan mufassirin lain bahawa frasa dan kalimah "al-ard al-muqdadasah" ( tanah suci) dalam ayat tersebut secara umumnya adalah merujuk kepada bumi Palestin. ${ }^{38}$ Manakala sebahagian dari mufassirīn seperti Ibn 'Abbās dan Qatādah mengkhususkan maksud "al-arḍ al-muqadasah" dalam ayat tersebut merujuk kepada wilayah al-Ṭur atau Arīha dan termasuk kawasan sekitarnya di Palestin. ${ }^{39}$

Seterusnya Nā'ilah menjelaskan bahawa, Nabi Musa a.s telah memperingatkan kaumnya dari kalangan Bani Israel, bahawa Allah SWT telah memerintahkan mereka untuk memasuki "al-ard al-muqadasah" tersebut, serta tidak berpaling atau lari ke belakang kerana takut untuk memerangi musuh di dalamnya. Demikian juga penjelasan Ibn Kathīr dalam tafsirnya, ${ }^{40}$ bahawa perintah Musa a.a kepada Bani Israel untuk berjihad memasuki Baitul Maqdis kerana pada ketika itu, kota suci tersebut telah dikuasai oleh kaum mustakbirīn 'Amāliqah yang kufur kepada Allah SWT. Nā'ilah menjelaskan bahawa perintah Mūsā AS tersebut disertai juga dengan peringatan dan amaran keras supaya jangan ada dalam kalangan mereka yang mengingkari perintah tersebut, jika tidak nescaya mereka akan mendapat dua kerugian iaitu kerugian di dunia dan di akhirat. ${ }^{41}$

\footnotetext{
38 Nā'ilah, al-Mubṣir li Nūr al-Qur'ān, 3: juz 6, 92.

39 Ibid., 93.

${ }^{40}$ Ibn Kathīr, Tafsìr al-Qur'ān al- 'Azīm, 2:

${ }^{41}$ Nā'ilah, al-Mubșir li Nūr al-Qur'ān, 3: juz 6, 92.
} 
Namun secara jelas, Bani Israel telah mengingkari perintah Musa a.s. Keingkaran Bani Israel telah mengakibatkan mereka menanggung kerugian. Hal sedemikian dapat dilihat pada hari ini, membuktikan paparan sebenar tentang sikap buruk dan perangai jahat golongan Zionis ${ }^{42}$ Yahudi. Al-Quran telah menjelaskan secara terang tentang golongan Yahudi yang dimurkai Allah SWT akibat keingkaran, kekufuran, kezaliman sikap melampaui batas mereka. Selain itu, mereka juga digambarkan dengan sikap penakut, bacul, degil dan takabbur yang cukup sinonim dengan perangai orang-orang Yahudi. Dalam hal ini, Nā'ilah Hāshim Șabrī menyifatkan sikap Yahudi dalam ayat ini sebagai sikap gelojoh, yang mahukan "kemenangan murah" tanpa perlu mereka berjihad dan bersusah payah untuk memilikinya. ${ }^{43}$

Ironinya, orang-orang Yahudi sehingga ke hari ini masih mendakwa dan menuntut bumi Palestin sebagai hak milik mutlak orang Yahudi semata-mata, atas dasar ia adalah "ard al-mī'a d" (bumi yang dijanjikan) untuk mereka sahaja, dan sesiapa sahaja tidak boleh mendiaminya kecuali orang-orang Yahudi. ${ }^{44}$

Seterusnya, mengupas maksud kerugian dalam ayat tersebut, ia dijelaskan oleh sebahagian dari mufassirin terdahulu dan para ulama semasa dengan merujuk kepada ayat ke 26 yang berikutnya:

42 Istilah Zionis terdiri daripada dua perkataan iaitu 'Zion' dan 'Isme'. Perkataan 'Zion' diambil daripada perkataan Ibrani (bahasa Yahudi) yang bermaksud 'batu'. Batu yang dimaksudkan di sini ialah ikatan batu bangunan istana atau 'Haikal'yang didirikan oleh Nabi Sulaiman di kota Al-Quds. Manakala 'Isme' pula (bahasa Inggeris) yang bermaksud 'fahaman' atau 'ajaran'. Oleh sebab itu, gabungan daripada 'Zion' dan 'isme' membentuk satu ideologi yang dianuti oleh bangsa Yahudi di seluruh dunia. Fahaman ini menyatakan bahawa bangsa Yahudi akan mendirikan sebuah kerajaan 'Israel Kubra' (Israel Raya) serta menjadikan kota Al-Quds ini sebagai ibu kotanya. Kesimpulanya, Zionisme adalah adaptasi daripada beberapa perkataan yang memberi makna yang menjurus kepada bentuk ideologi yang dianut oleh bangsa Yahudi sedunia dan ini telah menolak tanggapan bahawa Zionisme adalah satu gerakan yang didokong oleh mereka. Oleh itu, istilah ini sering di dengari dimana-mana kerana mereka menganut fahaman ini dan Zionis pula di guna pakai kepada bangsa Yahudi. Lihat Mohd Roslan Mohd Nor, "Konflik IsraelPalestin Dari Aspek Sejarah Moden dan Langkah Pembebasan dari Cengkaman Zionis”, Jurnal al-Tamaddun 5 (2004), 74.

43 Ibid., 93-94.

${ }^{44}$ Nā'ilah al-Mubșir li Nūr al-Qur'ān, 3: juz 6, 92. 'Ikrimah Sa'īd Sabrī, Haqqunā fì Falasținn (cet.ke-6, Amman: Dār al- Nafā'is, 2011), 10. 


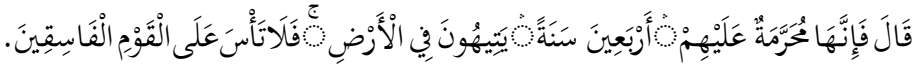

Al-Mā'idah 5:26

Terjemahan: "Allah berfirman; “(Jika demikian), maka sesungguhnya (negeri) itu diharamkan ke atas mereka selama empat puluh tahun, (selama itu) mereka akan merayau-rayau kebingungan (di sepanjang masa tersebut) di padang pasir Sinai). Maka janganlah kamu bersedih hati (memikirkan nasib) yang menimpa orang-orang fasik itu".

Berdasarkan keterangan al-Quran dan penjelasan para ulama, maka Nā'ilah Hāshim Șabrī menerangkan bahawa babak-babak kesukaran dan kesulitan yang dihadapi oleh Bani Israel tersebut merupakan satu bentuk pembalasan dan hukuman dari Allah SWT ke atas Bani Israel kerana mereka mengingkari perintah Musa a.s, juga pada asanya adalah balasan kerana keingkaran kepada perintah Allah SWT serta pelanggaran dan pemungkiran janji dengan Tuhan. Akibatnya, tanah suci yang asalnya ditentukan Allah SWT untuk Bani Israel, telah diharamkan ke atas mereka. Nā'ilah menjelaskan lagi bahawa bentuk pengharaman tersebut adalah pengharaman mutlak untuk selama-lamanya, dan bukannya pengharaman sementara yang terikat dengan sesuatu tempoh masa tertentu. $^{45}$

Dalam hal ini, dilihat bahawa pendapat Nā'ilah selari dengan beberapa tokoh dakwah dan ulama semasa yang turut membahaskan ayat-ayat berkaitan bangsa Yahudi tersebut. Antaranya ialah Sa'̄̄d Hawwā di dalam tafsirnya al-Asās fì alTafsì $r{ }^{46}$ menjelaskan bahawa Bani Israel dihukum sedemikian rupa kerana mereka menjadi manusia yang fasiq, kerana lari dari tanggungjawab jihad. Apabila mereka enggan menolong Mūsā AS Musa a.s untuk memerangi dan menegeluarkan golongan kuffar dari tanah suci supaya dapat ditegakkan agama Allah SWT padanya, maka ianya jelas bahawa mereka telah memungkiri

45 Ketika membuat tafsiran ayat ini, Nā'ilah Hāshim Șabrī turut mengulas tentang cara bacaan yang betul pada ayat tersebut, iaitu ketika mana sampai

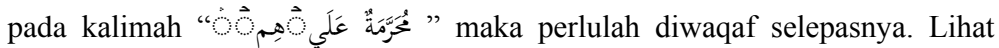
Nā'ilah, al-Mubșir li Nūr al-Qur'ān, 3: juz 6, 97.

46 Sa'īd Ḥawwā. al-Asās fì al-Tafsīr (cet.ke-4, Kaherah: Dār al-Salām,1993), 3. 
$m \bar{t} t h \bar{a} q^{47}$ dengan Allah SWT. Maka dengan sebab itu, sewajarnyalah mereka mendapat hukuman dan laknat dari Allah SWT.

\section{Kepentingan Masjid al-Aqsa}

Usaha untuk memahami dan menilai kepentingan Baitul Maqdis dan Masjid al-Aqsa menurut kaca mata Islam, maka asas penilaian utama sewajarnya berdasarkan kepada nas-nas yang sahih daripada kitab-kitab samawiyyah. Mengukuhkan lagi pandangan para ulama tentang kepentingan bumi Palestin bagi umat Islam, maka hal yang sama turut dibahaskan oleh Nā'ilah dalam tafsirannya berkaitan permasalahan Masjid al-Aqsa.

Secara tuntas, Nā'ilah menegaskan betapa pentingnya untuk membebaskan Baitul Maqdis dan Masjid al-Aqsa mengatasi isuisu lain yang ada pada hari ini. ${ }^{48} \mathrm{Di}$ samping itu juga, telah menjadi satu kewajipan bagi umat Islam untuk mengasihi dan mencintai Bait al-Maqdis dan Masjid al-Aqsa kerana kota suci ini disebut di dalam al-Quran sebagai salah satu tempat di bumi yang diberkati oleh Allah SWT termasuk kawasan di sekelilingnya. Hal sedemikian dirakam secara jelas dalam al-Quran dan hadith dalam pengkisahan peristiwa Isra' dan Mi'raj. Firman Allah SWT dalam ayat pertama surah al-'Isrā':

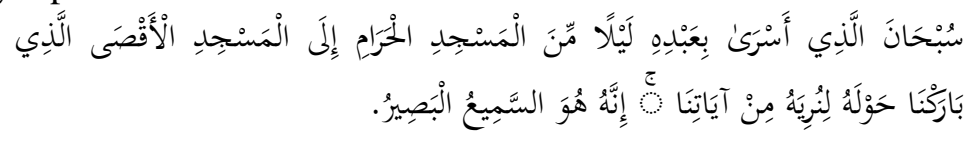

Al-'Isrā' 17:1

Terjemahan: "Maha Suci Allah yang telah menjalankan hamba-Nya (Muhammad) pada malam hari dari Masjid al-

\footnotetext{
47 Menerusi penelitian terhadap penggunaan kalimah mīthāq di dalam al-Quran, kebanyakan darinya adalah merujuk kepada maksud perjanjian di antara Bani 'Isrā'īl dengan Allah SWT melalui nabi-nabi yang diutuskan kepada mereka. Lihat al-Baqarah ayat 23, 63, al-Mā'idah: ayat 50, Āli 'Imrān: ayat 81,187. Pada tafsiran ayat 63 surah al-Baqarah, al-Ṭabarī menjelaskan bahawa kalimah mīthāq adalah satu kata nama daripada kalimah wathīqah yang merujuk kepada makna 'memberi persetujuan sama ada secara bersumpah ataupun secara aku janji'. Lihat Ibn Jārīr al-Ṭabarī, Jāmi ' al-Bayān 'An Ta'wīl Ayyi alQur'ān, 1: 421.

48 Nā'ilah Hāshim Șabrī, dalam temubual dengan pengkaji, di bilik 803 Hotel Impiana, Ipoh, Perak pada 11 Februari 2018, 2.45 petang.
} 
Haram (di Makkah) ke Masjid al-Aqsa (di Palestin), yang Kami berkati sekelilingnya, untuk memperlihatkan kepadanya tanda-tanda (kekuasaan dan kebesaran) Kami. Sesungguhnya Allah jualah Maha Mendengar dan Maha Mengetahui".

Menerusi tafsiran ayat ini, Nā'ilah menjelaskan bahawa Allah SWT telah memberkati Masjid al-Aqsa dan kawasan sekitarnya dengan pelbagai keberkatan, kerana ia merupakan bumi penempatan para anbiya', bumi tempat Rasulullah SAW di isra' kan dan permulaan kepada mi 'rajnya ${ }^{49}$. Ia juga bumi yang padanya terletak Masjid al-Aqsa ${ }^{50}$ yang menjadi kiblat pertama umat Islam. ${ }^{51}$ Nà'ilah turut menyenaraikan beberapa hadith yang menceritakan secara panjang lebar tentang proses peristiwa Israk dan Mikraj tersebut.

Walaupun ayat tersebut tidak menyebut secara khusus nama negeri tersebut, namun para mufassirin sepakat mengatakan bahawa ia adalah bumi Sham (Palestin), khasnya tanah suci Baitul Maqdis. Jika dirujuk kepada ayat pertama surah al-Isrā', secara jelas disebut di dalamnya Masjid al Aqsa yang terletak di Baitul Maqdis, Palestin. Seterusnya bumi yang berada di sekeliling Baitul Maqdis yang disebut sebagai bumi yang berkat itu adalah merujuk kepada bumi Syam (Palestin). ${ }^{52}$

Berdasarkan pandangan Shaykh Wahbah al-Zuhaylī di dalam tafsirnya, dinamakan Masjid al-Aqsa adalah disebabkan jaraknya yang jauh dari Masjid al-Haram. Adapun, ia juga merupakan masjid yang paling jauh daripada ahli Makkah di atas muka bumi

49 Isra' bermaksud perjalanan Rasullah SAW dari Masjid al-Haram ke Masjid al-Aqsa, manakala Mi 'raj pula merujuk kepada perjalanan baginda dari Masjid al-Aqsa ke langit.

${ }^{50}$ Dinamakan al-Aqsā merujuk kepada jaraknya yang jauh antara Masjid al-Aqsa dengan Masjid al-Haram. Lihat Ahmad Muhammad Yāsīn, al-Ta'rīf bi alMasjid al-Aqșā (Baitul Maqdis: Dār al-Risālah al-Maqdasiyyah li al-Ṭibā'ah wa al-Nasyr wa al-Tawzī', 2011), 14-18.

51 Nā'ilah, al-Mubșir li Nūr al-Qur'ān, 6: juz 15, 7.

52 Abū Ja'far Muhammad bin Jārīr bin Yaz̄̄d al-Ṭabarī, Jāmi ' al-Bayān 'An Ta'wīl Āyi al-Qur'ān (Beirut: Dār al-Fikr, 1988),10:405. Lihat juga Abū 'Abd Allāh Muhạmmad bin Abī Bakr bin Farḥ al-Anșārī al-Khazrajī al-Andalūsī alQurțubī, al- Jāmi ' li Ahkēam al-Qur'ān (Amman: Dār al-Fikr, 1993), 9: 212, 'Ismā'īl bin 'Amr bin Kathīr, Tafsīr al-Qur'ān al-'Az̄ìm (Riyadh: Dār alTaybah li al-Nashr wa al-Tawzī, 2009), 3: 961. 
ini, yang dituntut atau disyariatkan bagi umat Islam untuk menziarahinya. ${ }^{53}$ Al-Qurțubī turut menyatakan pandangannya berdasarkan penjelasan beberapa orang șahābah seperti Ibn 'Abbās r.a, bahawa bumi Palestin itu dianggap berkat, kerana tanahnya yang subur, pohon-pohonnya mengeluarkan buah, sungainya mengalir dan yang paling penting ia adalah tempat bersemadinya jasad ramai para Nabi dan hamba-hamba Allah yang soleh. ${ }^{54}$

Nā'ilah berpendapat, peristiwa-peristiwa besar ini amat bermakna dan mempunyai tujuan dan keistimewaannya yang tertentu dalam sejarah Islam. Antaranya pada awal surah al-Isrā', disebut perkaitan istimewa antara dua buah masjid, iaitu disebut masjid di Makkah sebagai Masjid al-Haram dan Masjid al-Aqsa disebut sebagai masjid yang penuh keberkatan. Selain itu, perkaitan sedemikian yang menjelaskan kedudukan Masjid alAqsa dan bumi Palestin ini turut disebut dalam kalangan mufassirīn firman Allah Ta'ala:

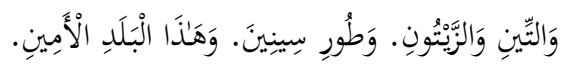

Al-Tīn 95:1-3

Terjemahan: "Demi buah tin dan zaitun. Dan gunung Tursina, serta negeri (Makkah) yang aman ini".

Berdasarkan tafsiran Nā'ilah, disebut lafaz buah zaitun dan buah tin yang dalam ayat-ayat tersebut adalah merujuk kepada keadaan muka di bumi Palestin, kerana Palestin adalah sebuah negara yang subur dengan pokok-pokok zaitun yang banyak ditanam terutamanya di kawasan perbukitan di Baitul Maqdis. Ia juga dikaitkan juga dengan bukit Sinai dan kota Mekah yang aman dan berkat. ${ }^{55}$

Nā'ilah menegaskan kepentingan Masjid al-Aqsa dalam Islam sehingga ia disebut secara jelas dalam hadith Nabi sebagai salah satu dari tiga Tanah Haram yang dituntut untuk bermusafir bagi menziarahinya. Bahkan, ia menjadi hujah kukuh kepada umat

53 Wahbah al-Zuhaylī, Tafsīr al-Munīr fi al-'Aqīdah wa al-Sharī'ah wa alManhaj (Beirut: Dār al-Fikr al-Mu'āṣir, 1991), 13:15.

${ }^{54}$ Abū 'Abd Allah Muḥammad bin Abī Bakr bin Farh al-Anșārī al-Khazrajī alAndalūsī al-Qurțubī, al- Jāmi' li Aḥkām al-Qur'ān (Amman: Dār al-Fikr, 1993), 11: 305.

55 Nā'ilah, al-Mubșir li Nūr al-Qur'ān, 11: juz 30, 468. 
Islam bahawa, tiada keutamaan dan keharusan yang paling utama bagi seseorang untuk bermufasir, kecuali bagi menziarahi tiga buah masjid iaitu Masjid al-Haram, Masjid al-Aqsa dan Masjid Nabawi ${ }^{56}$ Dalam hadith riwayat al-Bukhārī ada menyatakan:

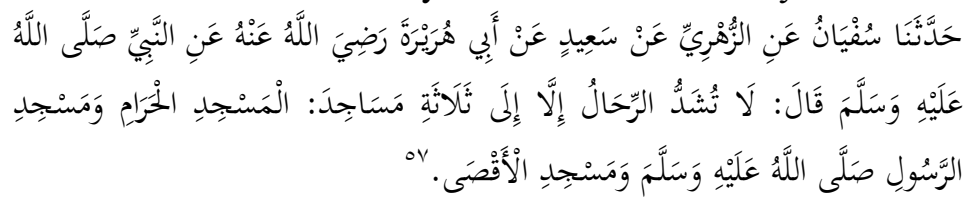

Terjemahan: Daripada Abū Hurayrah r.a, daripada Nabi Șallā Allāh 'alayhi wa sallam bersabda: "Tidaklah ditekankan untuk berangkat pergi (berziarah), kecuali ke tiga buah masjid; Masjid al-Haram, Masjid Rasulullah SAW dan masjid al-Aqsa".

Perkaitan yang lebih jelas tentang kepentingan Masjid alAqsa, dan hubungannya dengan aqidah umat Islam yang beriman dengan hari kiamat, yang didahului sebelumnya dengan beberapa peristiwa pada hari kebangkitan. Dalam hal ini, gambaran peristiwa tersebut dapat difahami menerusi kalam Allah SWT yang dirakamkan dalam surah Qaf ayat 41. Firman Allah SWT:

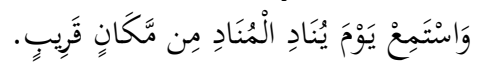

Qaf 50:41

Terjemahan: "Dan dengarlah, hari ketika malaikat penyeru, menyeru dari tempat yang dekat (yang dapat didengar)".

Dalam tafsiran ayat tersebut, Nà'ilah menegaskan bahawa signifikan ayat tersebut dengan Masjid al-Aqsa ialah pada frasa

56 Nā'ilah, al-Mubșir li Nūr al-Qur'ān, 6: juz 15, 5.

57 Hadith riwayat al-Bukhārī, Kitāb Faḍl al-Șalāh fī Masjid Makkah wa alMadīnah, Bāb Masjid Bayt al-Maqdis, no. hadith 1197. Lihat Ismā‘̄il ibn Ibrāhīm ibn al-Mughīrah ibn Bardizbah al-Ju'fī al-Bukhārī, "Ṣah̄ịh alBukhārî” dalam Jāmi ' al-Kutub al Tis 'ah; Hadith riwayat Muslim, , Kitāb alHajj, Bāb Lā Tashaddu al-Rihāa ilā Thalāthah Masājid, no.Hadith 1397. Lihat Muslim ibn al-Hajjāj ibn Muslim ibn Ward ibn Kawshān al-Qushayrī anNaysābūrī, "Șaḥị Muslim" dalam Jāmi ' al-Kutub al Tis 'ah; Hadith riwayat Abī Dāwūd, Kitāb al-Manāsik, Bāb F̄i Ityān al-Madīnah, no.Hadith 2033. Lihat Abu Dawud Sulaymān ibn al-Ash'ath al-Azdi as-Sijistani, "Sunan Ab̄̄ Dāwūd" dalam Jāmi ' al-Kutub al Tis 'ah; Hadith riwayat al-Nasā'̄, Kitāb alMasājid, Bāb Mā Tashaddu ilayhi min al-Masājid, no.Hadith 700. Lihat Abū 'Abd ar-Raḥmān Ahmmad ibn Shu ayb ibn Alī ibn Sīnān al-Nasā'ī, "Sunan alNasā'̄̄”' dalam Jāmi' al-Kutub al Tis 'ah. 
makān qarīb iaitu "tempat yang dekat". Mengulas dengan lebih lanjut, Nā'ilah menjelaskan bahawa ayat ini menjelaskan tentang keadaan yang berlaku apabila hampirnya hari kiamat, maka Malaikat yang menjadi penyeru akan menyeru dari tempat yang paling dekat dengan langit, iaitu dari atas Sakhrah Masjid al-Aqsa di Baitul Maqdis, ${ }^{58}$ dan seruan tersebut dapat didengari oleh semua makhluk bumi, dengan berkata: "Wahai tulang-tulang yang telah hancur dan daging-daging yang telah lumat, dan sendi-sendi yang telah terputus-putus, sesungguhnya Allah telah memerintahkan kepada kalian untuk berhimpun untuk menjalani keadilan". ${ }^{59}$

Sandaran hujah Nā'ilah bahawa 'tempat yang dekat' dengan langit tersebut adalah di Masjid al-Aqsa, diperkukuhkan lagi dengan mengemukakan pendapat al-Alūsi ${ }^{60}$ yang mendatangkan riwayat dari Ka'ab al-Ahbar dengan menyebut bahawa jarak 'tempat yang paling dekat' tersebut dengan langit adalah sejauh 18 $m \bar{l} l$ (batu). Berdasarkan pentafsiran ayat tersebut, Nā'ilah Hāshim Șabrī memperkukuhkan lagi pandangannya bahawa isyarat dari ayat al-Quran ini secara jelas menunjukkan keutamaan Baitul Maqdis dan kepentingan Masjid al-Aqsa dengan Allah SWT, sekaligus ia turut menjadi keutamaan bagi orang mukmin. ${ }^{61}$

Justeru, berdasarkan beberapa pentafsiran ayat al-Quran yang dikemukakan oleh Nā'ilah, secara jelas menunjukkan pemikiran Nā'ilah Hāshim Șabrī yang secara konsisten mengangkat isu Palestin dan Masjid al-Aqsa dalam tafsiran beliau, dengan tujuan meningkatkan kesedaran umat Islam tentang keutamaan terhadap isu membebaskan bumi Palestin dan Masjid al-Aqsa, lebih mengasihi dan mencintai Masjid al-Aqsa serta mengambil peduli apa yang berlaku terhadapnya.

58 Sependapat dengan sebahagian daripada mufassirīn terdahulu seperti Ibn Jarīr al-Ṭabarī, Ibn 'Abbās dan Qatādah, Nā'ilah turut menjelaskan bahawa yang dimaksudkan dengan" tempat yang paling dekat" tersebut ialah di atas Șakhrah Masjid al-Aqsa. Lihat Nā'ilah, al-Mubșir li Nūr al-Qur'ān, 10: juz 26, 217.

59 Ibid. Lihat juga Nā'ilah, “ Nidā’ Man 'Alā Șakhrah Bayt al-Maqdis” dalam F̄̄ Zilāl Āyah, 262.

60 Nā'ilah Hāshim Șabrī, al-Mubșir li Nūr al-Qur'ān, 10: juz 26, 217, Maḥmūd bin 'Abd Allāh Al-Alūsī, Rūhn al-Ma 'ānī fì Tafsīr al-Qur'ān al- 'Ażìm wa alSab 'ü al-Mathānī (t.tp: Dār al-Fikr, t.t.), 9: 194).

61 Nā'ilah, “Nidā' Man 'alā Șakhrah Bayt al-Maqdis” dalam F̄̄ Zilāl Āyah, 263. 
Ekoran dari itu, Nā'ilah turut mengingatkan umat Islam agar lebih perihatin dan mengambil 'ibrah dari peringatan-peringatan yang Allah rakamkan dalam al-Quran, terutama pendedahan tentang sikap buruk golongan Yahudi, yang tampak jelas sehingga ke hari in tidak putus-putus melakukan kerosakan dan kezaliman di atas muka bumi Palestin. Antara peristiwa yang dirakamkan adalah seperti yang terdapat dalam surah al-'Isrā':

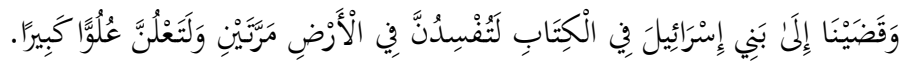

Al-'Isrā' 17:4

Terjemahan: "Dan Kami telah tetapkan kepada Bani 'Isrā'īl dalam kitab itu (al-Tawrāh); "Sesungguhnya kamu pasti akan melakukan kerosakan di bumi (Palestin) dua kali, dan sesungguhnya kamu pasti akan bersifat sombong lagi melampau".

Dalam tafsiran ayat tersebut, Nā'ilah memaparkan perkaitan fakta-fakta sejarah, dengan pembuktian dan kebenaran al-Quran terhadap kisah dan sikap Bani Israel bahawa mereka akan melakukan dua kali kejahatan besar di atas muka bumi Allah SWT. Kejahatan dan kerosakan kali pertama yang dilakukan oleh Bani Israel ialah apabila mereka menyelewengkan kebenaran yang terdapat dalam al-Tawrāh diikuti dengan menyakiti dan membunuh para Nabi antaranya ialah Zakariyya a.s dan Yahya a.s ${ }^{62}$ Manakala kejahatan dan kerosakan kali kedua yang dilakukan oleh Bani 'Isrā'īl ialah melalui penjajahan dan penaklukan Zionis Yahudi zaman ini yang masih berterusan melakukan pelbagai bentuk kezaliman dan pencabulan, dalam usaha mereka untuk melenyapkan kesucian kota Baitul Maqdis dan Masjid al-Aqsa, ${ }^{63}$ sekaligus mengangkat isu "bumi yang dijanjikan" untuk orang Yahudi sebagai agenda utama dalam siri penaklukan mereka ke atas kota Baitul Maqdis.

Tidak sekadar penegasan dalam al-Quran, bahkan sejarah hitam orang Yahudi juga disebut dalam kitab Tawrāh dan 'Injīl, yang menyebut bahawa orang-orang Yahudi adalah suatu bangsa yang terkenal dengan sikap angkuh dan sombong, bertindak secara

62 Ibid. ,6: juz 15, 10.

${ }^{63}$ Ibid. ,6: juz 15, 12-14. 
melampau serta biadap melakukan kerosakan di seluruh bumi Palestin terutamanya di Baitul Maqdis dan Masjid al-Aqsa. ${ }^{64}$

Pada ayat-ayat yang seterusnya, Allah SWT merakamkan bahawa setiap kejahatan dan kerosakan yang dilakukan oleh Bani 'Isrā'îl tersebut akan mendapat pembalasan dan hukuman yang dahsyat yang ditimpakan ke atas mereka. Kenyataan al-Quran ini disokong oleh kebanyakan mufassirin melalui pentafsiran mereka, yang bermula pada ayat 5 surah al-'Isrā':

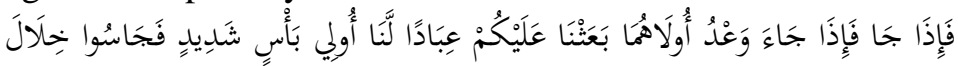

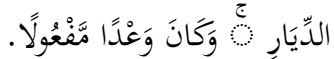

Al-Isrā' 17:5

Terjemahan: "Dan apabila sampai masa perjanjian (membalas perbuatan derhaka kamu) kali yang pertama dari dua (perbuatan derhaka) itu, Kami datangkan kepada kamu hamba-hamba Kami yang gagah dan amat ganas serangannya lalu mereka menjelajah di segala ceruk rantau (membunuh dan membinasakan kamu), dan ia satu janji yang pasti berlaku".

Nā'ilah turut menjelaskan bahawa kejahatan yang dilakukan Bani Israel telah menimbulkan kemurkaan Allah SWT, lalu

${ }^{64}$ Berdasarkan tafsiran ayat ini, Nā'ilah Hāshim Șabrī telah memaparkan di dalam beberapa karyanya secara terperinci tentang beberapa peristiwa yang merujuk kepada kerosakan yang dilakukan oleh golongan Yahudi pada hari ini.Antara peristiwa bersejarah yang menyayat hati penduduk Islam Palestin ialah apabila berlakunya tragedi Pembakaran Masjid al-Aqsa buat kali pertamanya pada 19 Ogos 1969. Dalam peristiwa tersebut, pihak rejim Israel telah menodai kesucian Masjid al-Aqsa dengan menceroboh masuk ke ruangan solat lalu dicampak keluar naskah-naskhah al-Quran sambil dipijakpijak oleh tentera-tentera Zionis tersebut. Kemuncak dari peristiwa tersebut ialah apabila tentera Zionis Israel mula mengganas dengan membakar mimbar dan kubah masjid. Peristiwa tragis tersebut turut menyaksikan kekentalan semangat umat Islam yang terdiri daripada para pemuda, kaum wanita bahkan kanak-kanak yang telah mengorbankan ratusan para syuhada' dan ribuan yang terkorban. Kebiadapan pihak rejim Zionis ini semakin menjadi-jadi apabila peristiwa yang hampir sama berlaku apabila Masjid Al-Aqsa dibakar buat kali kedua pada September 2015. (Rentetan peristiwa-peristiwa yang berlaku di bumi Palestin telah diabadikan oleh Nā'ilah dalam karya-karya penulisannya). Lihat Nā'ilah, al-Mubșir li Nūr al-Qur'ān, 6: juz 15, 14, Nā'ilah Hāshim Șabrī, Khawātị Nadiyyah wa Afkār Maqdasiyyah (Amman: Dār al-Nafā'is, 2014), 86-88. 
mereka menerima pembalasan yang dahsyat dari Allah SWt buat kali pertamanya dalam peristiwa pemusnahan Baitul Maqdis, apabila hampir seramai 70 ribu orang dalam kalangan Bani Israel telah dibunuh oleh Maharaja Nabukhaz yang memerintah Babylon ketika itu sehingga hampir terhapus etnik Bani Israel. ${ }^{65}$

Namun, sikap buruk dan perangai jahat golongan Yahudi ini tidak pernah berubah. Walaupun beberapa kali mereka menerima pembalasan dari Allah SWT, namun sikap degil dan sombong mereka menyebabkan mereka berulangkali mengingkari perintah Allah dan para rasul-Nya secara berterusan ${ }^{66}$ Hal yang sedemikian diperincikan oleh Nā'ilah dalam tafsiran ayat 8 surah al-'Isrā':

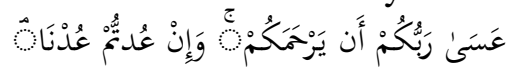

Al-Isrā' 17:8

Terjemahan: "Semoga Tuhanmu akan merahmatimu; dan jika kamu kembali (menderhaka) maka Kami akan menyeksamu".

Penjelasan lanjut tentang balasan penghinaan dari Allah Ta'ala ke atas sikap degil orang-orang Yahudi yang terus-menerus melakukan kerosakan di bumi serta berulangkali mengingkari perintah Allah dan para rasul-Nya, dinyatakan juga Nā'ilah ketika membuat tafsiran pada ayat 167 surah al-A'rāf:

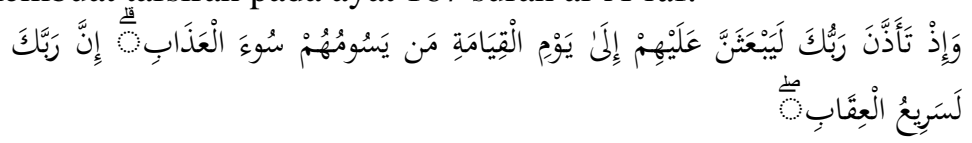

Al-A'rāf 7:167

'Terjemahan: Dan (ingatlah), ketika Tuhanmu memberitahu, "Bahawa sesungguhnya Dia akan menghantarkan kepada kaum Yahudi itu,(terus-menerus) sehingga hari kiamat, kaum-kaum yang akan menimpakan mereka dengan azab yang seburuk-buruknya. Sesungguhnya Tuhanmu amat cepat azab siksa-Nya, dan sesungguhnya Dia adalah Maha Pengampun lagi Maha Mengasihani”.

Nā'ilah menegaskan, balasan penghinaan Allah SWT ke atas orang-orang Yahudi akan diterima mereka sejak di dunia lagi.

65 Nā'ilah, al-Mubșir li Nūr al-Qur'ān, 6: juz 15, 11. Abū Ja'far Muhammad bin Jārīr bin Yazīd al-Tabarī, Jāmi ' al-Bayān 'An Ta'wīl Āyi al-Qur'ān (Beirut: Dār al-Fikr, 1988), 10:408

66 Ibid., 15. Lihat juga pada tafsiran ayat 18 -26 surah al-Mā'idah, al-Mubșir li Nūr al-Qur'ān, 3: juz 6, 86-97, al-Isrā' 17: 8. 
Antara buktinya ialah dalam peristiwa kekejaman Hitler yang telah membunuh ribuan orang-orang Yahudi. Bagi Nā'ilah Hāshim Șabrī, inilah antara bentuk azab yang dijanjikan Allah bahawa orang-orang Yahudi akan menerima azab seburuk-buruknya di dunia, manakala di akhirat juga mereka turut akan diazab dan dihina. $^{67}$

Justeru, Nā'ilah menegaskan sekali lagi bahawa isu pembebasan bumi Palestin dan Masjid al-Aqsa, merupakan persoalan yang wajar difahami dan dihadami sebagai suatu kewajipan jihad utama bagi umat Islam. Dalam hal ini, beliau menyatakan kebersamaannya dengan pendapat kebanyakan para ulama terdahulu dan terkemudian, bahawa menjadi suatu kewajipan fardu 'ain bagi umat Islam berjihad memerangi musuh yang menceroboh negara umat Islam. Sandaran pendapat tersebut diperkukuhkan dengan tafsiran ayat 274 surah al-Baqarah:

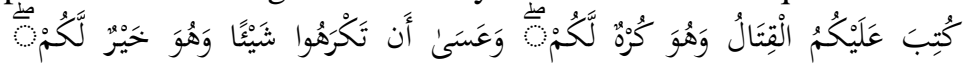

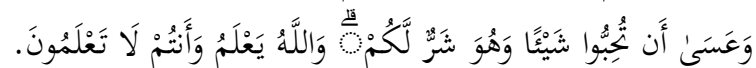

Al-Baqarah 2:216

Terjemahan: "Diwajibkan ke atas kamu berperang, (untuk menentang pencerobohan), sedangkan peperangan itu ialah perkara yang kamu benci; dan boleh jadi kamu benci sesuatu perkara padahal ia baik untuk kamu, dan boleh jadi kamu suka kepada sesuatu perkara padahal ia buruk bagi kamu. Dan (ingatlah, Allah jualah yang Mengetahui semuanya sedangkan kamu tidak mengetahuinya".

Sandaran hujah Nā'ilah dalam ayat ini turut dikemukakan menerusi tafsiran al-Qurțubī, dengan penjelasan bahawa berperang memerangi orang kafir yang menceroboh negara umat Islam adalah satu kewajipan fardu ain ke atas setiap individu muslim. ${ }^{68}$ Justeru bagi Nā'ilah, menjadi kewajipan seluruh dunia Islam untuk berjihad melawan Zionis Israel dengan apa jua bentuk yang diberikan, sama ada ketenteraan, senjata, harta serta seluruh kemampuan yang ada untuk membantu umat Islam Palestin. Ini

${ }^{67}$ Nā'ilah, al-Mubșir li Nūr al-Qur'ān, 6: juz 15, 15.

68 Muḥammad bin Aḥmad al-Anșarī al-Qurțubī, Jāmi ' li Ahkām al-Qurān (Beirut : Dār al-Kutub al-'Ilmiyyah, 1993), 2: 26. Lihat Nā'ilah, al-Mubșir li Nür al-Qur'ān, 1 juz 2 : 184-185. 
kerana isu Palestin tercatat sebagai isu pencerobohan ke atas peradaban kemanusiaan dan keagamaan.

Nada yang sama turut ditegaskan oleh Yūsuf al-Qarḍāwîn ${ }^{69}$ bahawa tiada jalan lain bagi umat Islam hari ini selain terus berjuang dan berjihad menentang Zionis Yahudi. Ini kerana, manusia apabila ditindas dan terus ditindas, maka mereka akan bangkit dengan kekuatan dan keyakinan yang ada, begitulah juga umat Islam di Palestin. ${ }^{70}$

Dalam isu pembebasan Palestin, Nā'ilah turut membincangkan persoalan yang berkaitan dengan hukum menziarahi Masjid al-Aqsa, dalam konteks yang lebih relevan dengan maslahah ummah pada hari ini. ${ }^{71}$ Dalam hal ini, pendapat Yūsuf al-Qarḍāwī turut diperbahaskan dari sudut pro dan kontranya. Ini kerana al-Qarḍāwī berpendapat, menziarahi Masjid al-Aqsa buat masa sekarang yang masih di bawah jajahan rejim Zionis Yahudi adalah haram ${ }^{72}$ bagi setiap umat Islam, terkecuali bagi rakyat Palestin sendiri. Bagi al-Qarḍāwī, dengan lawatan menziarahi Masjidi al-Aqsa secara lansung akan memberikan keuntungan material, psikologi serta pengaruh politik kepada Zionis Israel, dan ia dianggap mengiktiraf kewujudan kerajaan Israel ke atas Palestin. ${ }^{73}$

69 Y ūsuf al-Qaraḍāwī, merupakan seorang ulama tersohor dalam dunia hari ini. Beliau yang menjadi Ketua Kesatuan Ulama Sedunia cukup terkenal dengan ketokohan dan keilmuan beliau dalam pelbagai cabang ilmu agama.

70 Yūsuf al-Qarḍ̄āī, Al-Aqsa Tanah Wakaf Umat Islam: Khuțah al-Shaykh Yūsuf al-Qaraḍ̄̄wī Nafahāt al-Jum 'ah, terj. Arsil Ibrahim (Kuala Lumpur: Ana Muslim Sdn.Bhd, 2014 ).

71 Dibaca dengan maksud negara Palestin di bawah penguasaan Israel.

72 Yūsuf al-Qard̦āwī, Al-Aqsa Tanah Wakaf Umat Islam: Khuțbah al-Shaykh Yūsuf al-Qarad̄ōwī Nafahāat al-Jum 'ah, 2-8.

73 Selain siaran fatwa secara khusus dalam karya penulisan, umum juga boleh melihat kenyataan-kenyataan Yūsuf al-Qarḍāwī berkenaan Palestin dalam beberapa laman sesawang dan media sosial. Antaranya ialah "Al-Qarḍāwī Yuharrim Mujaddadan Ziyārah al-Quds", laman sesawang al-Jazeera, dikemaskini 13 Julai 2010, dicapai 25 April 2018, http://www. aljazeera. net/ news/ arabic /2010/7/13/\%D8\%A7\%D9\%84\%D9\%82\%D8\%B1\%D8\%B6\%D8. Lihat juga Mohamed Shaker, "Al-Qaraḍāwī: Ziyārah al-Quds li Ghayr al-Palasținiyyīn Haram Shar'an", laman sesawang YouTube, dikemaskini 17 Jun 2012, dicapai 25 April 2018, https:// www. youtube.com/watch?v=bGkiJyUQdOU. 
Walau bagaimanapun, Nā'ilah tidak bersependapat dengan alQarḍāwī dalam mengulas persoalan dan hukum menziarahi Baitul Maqdis dan Masjid al-Aqsa. ${ }^{74}$ Malah beliau lebih bertegas dalam membuat gesaan agar lebih ramai umat Islam dari luar negara Palestin datang menziarahi Masjid al-Aqsa. ${ }^{75}$ Pendapat beliau juga selari dengan fatwa 'Ikrimah Sa'̄id Sabrī ${ }^{-76}$ dalam membuat gesaan agar umat Islam menziarahi Masjid al-Aqsa. ${ }^{77}$

74 Dalam temubual dengan pengkaji, Nā'ilah menegaskan bahawa pendapat beliau adalah berdasarkan pengalaman dan realiti suasana semasa yang berlaku di Baitul Maqdis. Ia sekaligus bertepatan dengan pendapat serta fatwa suaminya 'Ikrimah Sa'īd Șabrī,yang telah membuat gesaan untuk menziarahi Masjid al-Aqsa.

75 Ketika temubual pengkaji bersama Nā'ilah, beliau mengulangi pendiriannya dalam persoalan 'shadd al-rihâal ilä al-Aqșā' (tuntutan ziarah ke Masjid alAqsa) bahawa menjadi tuntutan bagi seluruh umat islam datang ke Masjid alAqsa. Temubual pengkaji dengan Nā'ilah di Bilik 3005, PNB Perdana Hotel \& Suites, 10 Jalan Binjai, Kuala Lumpur, pada 21 Oktober 2018 jam 10.30 pagi.

76 'Ikrimah Sa'īd Șabrī adalah salah seorang ulama dunia yang turut bersamasama dengan Yūsuf al-Qaraḍāwī dalam gerak kerja dakwah memacu ummah menerusi penglibatan mereka dalam Kesatuan Ulama Islam Sedunia. Bermula dari tahun 2012, 'Ikrimah Sa'īd Șabrī diberi amanah memegang jawatan sebagai salah seorang Ahli Majlis al-Umanā' Kesatuan Ulama Sedunia. Sehingga kini, nama 'Ikrimah Sa'īd Șabrī semakin dikenali dunia menerusi suara yang dibawa beliau sebagai Imam Besar dan Khatib Masjid al-Aqsa dalam mengetengahkan isu Palestin dan Masjid al-Aqsa keseluruh ceruk dunia. Beliau dilihat tetap konsisten dengan prinsip dan pegangannya, walaupun seringkali mendapat pelbagai tekanan dan ancaman, bahkan pernah dilucut jawatan sebagai Mufti al-Quds (2006) ekoran dari fatwa-fatwanya yang dilihat memberi ancaman kepada pihak Zionis Yahudi.Yang terkini pada 1 Mei 2018, pihak Kementerian Dalam Negeri Israel telah mengeluarkan surat arahan penahanan (dari keluar dari negara Palestin selama sebulan serta dilarang memasuki kawasan Tebing Barat selama empat bulan), sekaligus membuat penangkapan terhadap 'Ikrimah Sa'īd Șabrī (selama sehari untuk disoal siasat) di atas dasar memberi ancaman keselamatan. Lihat "Is'al-Shaykh 'Ikrimah Șabrī 'An Qiyām al-Iḥtilāl bi Farḍ al-Iqāmah al-Jabariyyah 'Alayh" laman sesawang al-Jazeera Mubasher, dimuatnaik pada 4 Mei 2018, dicapai 19 Mei 2018, https://www.youtube. com/watch?v=ZA-n8 DLKNE8 \&t=686s.

77 Secara konsisten dan khusus, 'Ikrimah Sa'īd Șabrī telah mengeluarkan fatwa khusus yang mewajibkan 'shadd al-rihâal ilā al-Aqșā' ke atas setiap penduduk Palestin terutama yang tinggal di sekitar Baitul Maqdis untuk mengimarahkan Masjid al-Aqsa setiap kali waktu solat fardu, walaupun terpaksa berhadapan dengan ancaman dari pihak tentera Israel. Lihat 'Ikrimah Sa'̄̄d Șabrī, "Thawāb al-Ladhī Yashuddu al-Riḥāl ilā al-Aqșā̄" dalam Fatāwā 
Mengukuhkan lagi pendirian beliau, Nā'ilah bertegas menyatakan bahawa pada hakikatnya, isu Palestin dan Masjid alAqsa hanya dapat difahami dengan baik sekiranya umat Islam di luar negara Palestin dapat datang ke Palestin dan menziarahi Masjid al-Aqsa, lalu dapat melihat dan merasai sendiri pengalaman sebenar bersama dengan penduduk Islam Palestin.

Bagi Nā'ilah, selain dapat membantu menjana ekonomi ${ }^{78}$ penduduk Palestin yang masih tinggal di kem-kem pelarian atau di kawasan-kawasan penempatan warga Palestin yang di bawah kawalan tentera Israel, maka dengan kedatangan saudara seislam dari negara luar dapat menguatkan lagi semangat perjuangan Islam untuk saling bantu-membantu. Begitu juga ia mampu mewujudkan banyak ruang perbincangan antara saf pimpinan umat Islam luar dengan pemimpin-peminpin Islam di Palestin bagi penyelesaian masalah ummah.

Dalam usaha membangkitkan semangat para pemuda dan kaum wanita Palestin untuk terus bangkit mempertahankan Palestin dan Masjid al-Aqsa, Nā'ilah membawa konsep "labbayk $y \bar{a}$ Aqș̄a $"{ }^{79}$ Ia adalah sebagai salah satu cara yang dibuat bagi menyentap hati umat Islam yang berada di luar bumi Palestin

Maqdasiyyah (Amman: Dār al-Nur al-Mubīn li al-Dirāsāt wa al-Nashr, 2011), 443-444. Pada masa yang sama, ketika temuabual pengkaji dengan beliau, Shaykh 'Ikrimah Șabrī menegaskan bahawa perlunya umat Islam dari luar Palestin yang mempunyai kemampuan untuk menyahut seruan Nabi SAW untuk menziarahi Masjid al-Aqsa.agar dapat melihat dan meletakkan rasa kebersamaan mereka dengan masyarakat Islam Palestin dalam isu pembebasan Palestin. 'Ikrimah Sa'īd Șabrī dan Nā'ilah Hāshim Șabrī, dalam temubual dengan pengkaji, di Bilik 2612, PNB Perdana Hotel \& Suites, No.10 Jalan Binjai, Kuala Lumpur, pada 2 November 2017, jam 2,30 petang.

78 Walaupun hanya memperolehi hasil pendapatan yang sedikit, namun menurut Nā'ilah, penjanaan ekonomi dalam kalangan penduduk Islam Palestin sedikit sebanyak dapat dibantu melalui pembelian hasil barangan kraftangan dan industri kecil barang-barang yang dihasilkan sendiri oleh masyarakat Islam Palestin, di samping yang paling utama ialah adanya usaha-usaha untuk membawa suara rakyat Palestin ke dunia luar melalui hebahan yang dilakukan oleh pengunjung dari luar Palestin. Lihat " 'Ikrimah Șabrī ' Yad'ù li Shadd alRiḥāl li al-Masjid al-Aqșā al-Khamīs al-Qādim”, laman sesawang al-Najāh al'Ikhbārī, dimuatnaik pada 25 November 2017, dicapai 19 Mac 2018, https://nn.ps/news/flstynyt/2017/11/25/71767/.

79 Nā'ilah Hāshim Șabrī, "Labbayk yā Aqșā", dalam Khawātirir Nadiyyah wa Afkār Maqdasiyyah, 89. 
untuk bangkit menyatakan kebersamaan mereka dengan umat Islam Palestin. Bahkan beliau meletakkan harapan yang tinggi kepada seluruh umat Islam untuk tetap teguh bersatu dan bersama atas landasan yang sama, taat setia dan berkorban bagi menyokong perjuangan membebaskan bumi Palestin. ${ }^{80}$

Bagi Nā'ilah Hāshim Șabrī, umat Islam perlu terus-menerus memerangi Zionis Israel bukan kerana semata-mata mereka bangsa Yahudi, tetapi adalah kerana golongan Yahudi ini telah merampas tanah hak milik umat Islam, melampaui batas kemanusiaan, mencerobohi kehormatan rakyat Palestin, menumpahkan darah, memusnahkan Masjid al-Aqsa serta memerangi orang Islam seluruhnya. Kesemua kejahatan dan kerosakan yang dilakukan oleh Yahudi telah membawa bencana yang besar kepada umat Islam. Justeru, menjadi kewajipan kepada seluruh umat Islam di seluruh dunia untuk terus-menerus istiqamah dan bersama meyokong dan mendokong segala usaha dan langkah untuk membebaskan kembali bumi Palestin yang menjadi hak milik orang Islam. ${ }^{81}$

\section{Kesan dan Ancaman Yahudi Ke atas Bumi Palestin}

Bagi Nā'ilah, isu Palestin dan segala permasalahan yang berkaitan dengannya sewajarnya menjadi isu yang mendominasi umat Islam sejagat. Tidak sekadar membawaa isu pembebasan Palestin dan Masjid al-Aqsa, malah isu-isu lain yang berkaitan dengan kebajikan umat Islam Palestin dari aspek keselamatan dan kesihatan, status kewarganegaraan, tahap pendidikan serta sosio budaya dan ekonomi merupakan antara isu dan permasalahan utama yang masih belum ada jalan penyelesaiannya sehingga kini. Justeru, antara isu utama yang diangkat dalam kajian ini ialah:

1. Hak pemilikan tanah di Palestin.

2. Krisis identiti warganegara.

3. Peranan Murabițāt dan Jīl al-Tahrī̄r (Generasi Pembebas).

${ }^{80}$ Ibid., Lihat juga Nā'ilah Hāshim Șabrī, Palesțīniyyah Sa'abqā, 14, al-Mubșir li Nür al-Qur'ān, 1: juz 2, 183-185.

81 Nā'ilah Hāshim Șabrī (Pengarang al-Mubșir li Nūr al-Qur'ān), dalam temubual dengan pengkaji, di bilik 803 Hotel Impiana, Ipoh, Perak pada 11 Februari 2018, 2.45 petang ( sempena lawatan beliau bersama suaminya ke Malaysia, dalam siri jelajah negara bagi pengisian program 'al-Quds Lanā' yang dianjurkan oleh pertubuhan Aman Palestin. 


\section{Hak Pemilikan Tanah di Palestin}

Hakikatnya, dalam dunia kontemporari hari ini, kita melihat Palestin sebagai sebuah negara yang tertakluk di bawah penguasaan Zionis Yahudi. Ini kerana Zionis Yahudi telah mewujudkan lakaran peta dunia baru dengan penubuhan negara Israel di atas tanah yang dirampas dari penduduk Islam Palestin. Suatu tindakan dan perbuatan yang paling hina yang turut mendapat sokongan kuasa-kuasa besar British dan Amerika.

Dalam hal ini, Nā'ilah terus memberi peringatan agar umat Islam tidak menyepi dalam permasalahan bumi Palestin. Ini kerana orang-orang Yahudi ingin merubah dan mencabut sejarah Palestin sehingga ke akar umbinya dengan pelbagai bentuk pemalsuan dan penipuan. Walaupun semua fakta sejarah dan nas membuktikan bahawa Palestin adalah bumi milik orang Islam, namun politik perluasan penempatan Yahudi telah memberikan keutamaan penguasaan ke atas Baitul Maqdis berpihak kepada mereka. Ia dijayakan dengan strategi menguasai tanah dan tempat tinggal dan memberikan hak penempatan kekal kepada orangorang Yahudi. Tanah-tanah kediaman warga Palestin dirampas, rumah-rumah mereka dirobohkan seterusnya penduduk Palestin diusir dari kampung halaman mereka.Tidak hanya terhenti dengan usaha-usaha jahat untuk meruntuhkan Masjid al-Aqsa, bahkan projek penubuhan negara Israel bermula dengan perampasan bumi Palestin dari penduduknya dengan cara kekerasan, pembunuhan, pengusiran dan perampasan segala apa yang ada padanya. ${ }^{82}$ Kemuncak kepada penubuhan negara Israel di atas bumi Palestin adalah hasil dari Resolusi 181 (II) oleh Majlis Perhimpunan Agung Pertubuhan Bangsa-Bangsa Bersatu (PBB) pada 29 November 1947. Keputusan tersebut membenarkan penubuhan dua buah negara, satu untuk orang Arab dan satu lagi untuk orang Yahudi. Keputusan Perhimpunan Agung PBB itu juga memutuskan bahawa wilayah Baitul Maqdis adalah di bawah pentadbiran antarabangsa khas di bawah $\mathrm{PBB} .{ }^{83}$ Bagaimanapun,

82 İmān 'Ismā‘̄il, “Zaujah 'Ikrimah Șabrī Turșad Mu'ānah al-Mar'ah alMaqdasiyyah", laman sesawang Lajnah al-Quds, dikemaskini 1 April 2012, dicapai 5 Febuari 2012, http:// www. alquds.gov.ps/ar/?view=79YO cy0nNs3Du 69tjuhzy1wkyeayxx\% 2B7\%2 Fan zy Ahk Xwe IT9jMURkT.

83 "Pelan Pembahagian Pertubuhan Bangsa-Bangsa Bersatu untuk Palestin", laman sesawang WikiMedia Indonesia, dikemaskini 11:30, 9 Mac 2013, 
pelan pembahagian tersebut tidak dapat dilaksanakan sepenuhnya. Setelah itu, rejim Zionis telah melancarkan pelbagai bentuk dakyah dan propaganda bagi menimbulkan kekeliruan fakta dalam kalangan orang Islam sendiri. Hal sedemikian terus-menerus berlaku sehingga ke hari ini.

Tidak sekadar itu, rejim Zionis Yahudi telah mengambil beberapa langkah pencerobohan ke atas Bandar Baitul Maqdis dengan mencabar badan-badan antarabangsa dan ketetapanketetapannya dengan pelbagai dakwaan palsu dan penipuan. Antaranya ialah dengan meluaskan projek-projek penempatan Yahudi yang telah dibina melinkungi kawasan penempatan penduduk Palestin di Baitul Maqdis. Bahagian penempatan Yahudi di sambung antara satu sama lain sehingga tiada lagi kawasan penempatan yang menghimpunkan penduduk Palestin di Bukit Skuwis. Maka kekal lah rumah-rumah penduduk Palestin yang lama di Sya'fat dengan saiz yang kecil dihimpit oleh penempatan Yahudi yang baru dibina yang tampak gah mengelilinginya. ${ }^{84}$

Persoalan tentang penempatan dan pemilikan tanah di Palestin, sering mengundang pelbagai persepsi dan sangkaan buruk masyarakat luar dari Palestin. Dengan keterbatasan ruang dan peluang yang ada, Nā'ilah tetap berusaha mengambil pendekatan untuk menangkis setiap tohmahan dan tuduhan palsu tersebut, samada menerusi kenyataan-kenyataan akhbar seperti alQuds, al-Ra'y mahupun secara lisan di lapangan seminar, kuliah atau ceramah.

Dalam hal ini, Nā'ilah menyatakan kekesalannya dengan sikap sebahagian umat Islam yang mempercayai propaganda yang diwujudkan oleh pihak Zionis, berhubung isu pemilikan tanah penduduk di Palestin. ${ }^{85}$ Menurut beliau, antaranya ialah tuduhan bahawa penduduk Palestin bertanggungjawab sepenuhnya atas

$\begin{array}{llll}\text { dicapai } & 1 & \text { Mac }\end{array}$ ttps://ms.wikipedia.org/wiki/Pelan_Pembahagian_Pertubuhan_Bangsa-bangsa _Bersatu_untuk_Palestin.

84 Abdul Hadi Awang, Palestin Daripada Perampas Jalanan Kepada Peta Jalanan (Kuala Lumpur: Jundi Resource, 2010 ), 39-41.

85 Semasa siri lawatan beliau bersama suaminya ke Mesir pada tahun 2003, dalam sebuah program seminar antarabangsa yang membincangkan isu Palestin. 
kesalahan mereka kerana menjual tanah-tanah di Palestin kepada Zionis Yahudi. Bagi menangkis tuduhan tersebut, Nā'ilah bersama suaminya 'Ikrimah Sa'īd Șabrī, merupakan antara individu yang sering terkedepan untuk memberi pencerahan. ${ }^{86}$ Antara yang dapat dilihat ialah menerusi penjelasan Nā'ilah menerusi liputan akhbar al-Quds. ${ }^{87}$ Antara petikan ucapan beliau ialah:

$$
\begin{aligned}
& \text { وأود أن أوضح أنه بعد وعد بلفور المشئوم في 1917، سمح لليهود بالهجرة إلى ألى }
\end{aligned}
$$

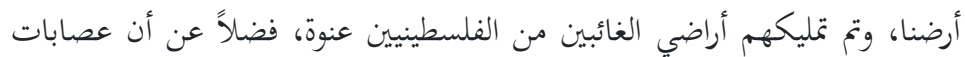

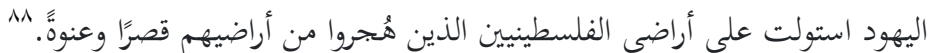

"Aku ingin tegaskan bahawa selepas Perjanjian Balfour yang termeterai pada tahun 1917, orang-orang Yahudi dibenarkan untuk berhijrah ke negara kami, mereka telah merampas tanah-tanah penduduk Palestin dengan cara paksaan dan taktik kotor."

Akibat dari peristiwa itu, penduduk Palestin terpaksa mengosongkan tanah-tanah mereka hasil tipu muslihat Zionis Yahudi yang memaksa para wanita yang kebanyakannya terdiri daripada para wanita dan janda, untuk menandatangani beberapa pucuk surat dalam bahasa 'Ibri yang tidak difahami mereka. Ia mengakibatkan mereka kehilangan hak milik ke atas tanah-tanah tersebut, bahkan dihalau keluar dari kediaman mereka, diancam dan dibunuh, dan akhirnya mereka terpaksa mendiami khemahkhemah pelarian.

Walaupun sering diancam oleh pihak Zionis Yahudi dengan pelbagai ancaman keselamatan berbentuk fizikal dan spiritual, ia

${ }^{86}$ Isu penjualan tanah di Palestin merupakan isu yang telah lamadiberi perhatian oleh para ulama Palestin. Antaranya ialah Sa'īd Șabrī, iaitu bapa kepada 'Ikrimah Sa'̄id Șabrī, merupakan seorang Mufti di al-Quds, telah mengeluarkan fatwa khusus tentang pengharaman menjual tanah Palestin kepada orang-orang Yahudi. Lihat laman sesawan Youtube-AlGhad TV, "AlQuds: Wujūh Maqdasiyyah ; al-Shaykh Sa 'īd Șabrī Qāọī al-Quds al-Sharīf”, $\begin{array}{llll}\text { dicapai } & \text { pada } & 10 & \text { Januari }\end{array}$ https://www.youtube.com/watch?v=i21yI38B1IA.

87 “Zaujah 'Ikrimah Șabrī Turșad Mu'ānah al-Mar'ah al-Maqdasiyyah", laman sesawang Lajnah al-Quds, dicapai 7 Januari 2013, http://www.alquds.gov.ps/ar/?view=79Yocy0nNs3Du69tju hzy1wkyeayxx\%2B7\%2FAnzy AHkXWeIT9jMURkT

Ibid. 
tidak memudarkan semangat Nā'ilah untuk terus tetap bersama rakyat Palestin mempertahankan kedaulatan tanah air mereka. Bagi beliau, tidak wajar baginya hatta bagi sesiapapun untuk meninggalkan perjuangan semata-mata untuk mendapatkan keselesaan hidup. Ini dibuktikan apabila beliau menolak pelawaan untuk berhijrah negara lain yang lebih kondusif dan aman untuk beliau meneruskan perjuangan hidupnya.

Walau apa pun yang berlaku, Nā'ilah tetap menyeru agar seluruh umat Islam Palestin untuk terus mempertahankan bumi Baitul Maqdis walau dengan ruh dan darah mereka dan tidak sekali-sekali berganjak meninggalkan tanah air walau pun seinci. ${ }^{89}$ Bahkan tekad dan keazaman beliau untuk terus berjihad dan berada di jalan dakwah tetap utuh, kerana meyakini janji-janji Allah Ta'ala; ${ }^{90}$

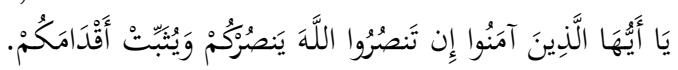

Muhammad 47:7

Terjemahan: "Wahai orang-orang yang beriman, jika kamu menolong (membela) agama Allah, nescaya Allah akan menolong kamu (untuk mencapai kemenangan) dan akan meneguhkan tapak (pendirian) kamu".

\section{Krisis Identiti Warganegara}

Nā'ilah Hāshim Șabrī mendedahkan wujudnya perancangan jahat musuh-musuh Islam di peringkat antarabangsa dan setempat bagi menghapuskan sebarang perkaitan yang melibatkan isu Palestin dengan umat Islam. Antaranya ialah usaha untuk menjadikan isu Palestin di dalam ruang lingkup 'așābiyyah perkauman dan sempadan geografi yang sempit. Akibat yang paling ketara ialah penduduk Islam Palestin menghadapi ancaman kehilangan identiti mereka sebagai warganegara Palestin.

${ }^{89}$ Lihat laporan yang disediakan oleh wartawan Īmān Ismā'īl ketika temuramah bersama Nā'ilah yang dimuat turun dalam "Zaujah 'Ikrimah Șabrī Turșad Mu'ānah al-Mar'ah al-Maqdasiyyah", laman sesawang Lajnah alQuds, dikemaskini 1 April 2012, dicapai 5 Febuari 2012, http://www.alquds.gov.ps/ar/?view =79YOcy0nN s3Du69tjuh zy1wkyeayxx\%2B7\%2FAnzy AHkXWeIT9jMURkT.

90 Nā'ilah, al-Mubșir li Nūr al-Qur'ān, 10: juz 26, 61. 
Melalui pengalaman jerih-perih di tanahairnya, Nā'ilah menggambarkan situasi serta ancaman yang terpaksa dihadapi oleh penduduk Palestin menerusi satu sidang akhbar al-Quds;

"Aku dan suamiku sama seperti warga al-Quds yang lain, terpaksa meninggalkan kediaman kami di Tebing Barat dan tinggal di sebuah rumah pangsa di al-Quds, agar kami tidak akan kehilangan identiti kami sebagai warga al-Quds. Pernah suatu hari suamiku dipanggil oleh pihak Zionis Yahudi, bagi memberi amaran kepadanya bahawa suatu hari nanti mereka akan mencabut identiti kami sebagai warga al-Quds, kerana kami banyak menghabiskan masa kami di kediaman kami di Tebing Barat berbanding dengan baki-baki hari kami di alQuds. Bahkan pihak Zionis juga telah menyewa sebuah bangunan berhadapan dengan rumah kami di Tebing Barat, bagi mengawasi pergerakan kami serta bagi memastikan agar kami tidak lagi mengunjungi rumah kami di Tebing Barat. Selain itu, kami juga dilarang untuk mengambil apa-apa barang milik kami di Tebing Barat untuk dibawa ke alQuds"

Selain insiden pembakaran Masjid al-Aqsa kali pertama pada 19 Ogos $1969,{ }^{92}$ berlakunya beberapa peristiwa yang lain yang banyak memberi kesan besar kepada kehidupan Nā'ilah sekeluarga. Antara orang yang banyak menerima tekanan dan ancaman dari pihak Israel ialah suami beliau sendiri iaitu 'Ikrimah Sa'̄̄d Șabrī. Dengan posisi beliau yang memegang jawatan sebagai Imam dan Khatib Masjid al-Aqsa dan Mufti al-Quds serta pelbagai posisi penting yang lain dalam pertubuhan-pertubuhan Islam di Palestin, 'Ikrimah Sa'̄̄d Șabrī dilihat sebagai salah satu ancaman

91 Lihat laporan tersebut dalam "Zaujah 'Ikrimah Șabrī Turșad Mu'ānah alMar'ah al-Maqdasiyyah", laman sesawang Lajnah al-Quds,dikemaskini 1 April 2012, dicapai 5 Febuari 2012,http://www.alquds.gov.ps/ar/.?view= 9Yocy 0nNs3Du69tjuhzy1wkyeayxx\%2B7\%2FAnzAhkXW eIT 9jMURkT.

92

Catatan peristiwa ini dirakamkan dalam sebuah artkel yang berjudul "Labbayk Yā Aqșā" yang dimuatkan dalam karya pertama tulisanNā'ilah pada tahun 1972 yang berjudul Wamdah fì Zulām. Lihat Wamdah fì Zulām (cet.ke-2, Jerusalem : Mațābi‘ al-Quds al-‘Arabiyyah,1978. 
besar kepada pihak Zionis Yahudi. Hal sedemikian turut memberi impak yang besar kepada Nā'ilah serta anak-anaknya. ${ }^{93}$

Bagi Nā'ilah Hāshim Șabrī, usaha untuk mengasaskan negara Israel adalah satu usaha untuk memutuskan jalan-jalan berkaitan agama, politik, sejarah dan kewarganegaraan. Antaranya ialah dengan cara pemisahan di antara dua status warganegara iaitu warganegara Palestin dan warganegara Israel. Ia bermula dengan tindakan pihak Israel yang mengenakan pelbagai syarat ketat ke atas penduduk Islam Palestin terutamanya bagi mereka yang masih kekal mendiami di dalam kawasan penempatan dalam wilayah Palestin.

Semenjak tahun 2002, Mahkamah Agung Israel menguatkuasakan undang-undang yang mencegah pemberian status kewarganegaraan dan keizinan untuk tinggal terhadap warga wilayah Palestin yang berkahwin dengan warga wilayah Israel. ${ }^{94}$. Alasan bagi peraturan tersebut adalah atas dasar warga Palestin akan menjadi ancaman bagi keamanan negara Israel. ${ }^{95}$

Dalam situasi begini, kaum wanita merupakan golongan yang paling ketara menerima kesan buruk tersebut. Menurut Nā'ilah, ramai wanita Palestin yang memilih jalan untuk tidak berkahwin dan terpaksa menolak lamaran dari lelaki yang meminangnya. ${ }^{96}$

93 Pihak Zionis Israel sering memberi tekanan kepada keluarga Nā'ilah Hāshim Șabrī bagi merencatkan kemaraan masyarakat Islam Palestin khususnya di Baitul Maqdis. Antaranya ialah peristiwa "Penutupan Masjid al-Aqsa" bermula pada 20 Julai 2017 ekoran dari beberapa kenyataan 'Ikrimah Sa'îd Șabrī yang dimuat naik dalam status laman sosialnya berkaitan Shadd al-Rihāl ilā al-Aqșā (Gesaan Mengunjungi Masjid al-Aqsa). Dalam peristiwa tersebut, 'Ikrimah Sa'īd Șabrī telah mengalami kecederaan akibat terkena tembakan peluru getah.

94 Semenjak tahun 1993, lebih dari ratusan ribu rakyat Palestin telah mendapat keizinan sementara untuk tinggal di wilayah-wilayah yang ditakluki Israel. Namun, keadaan sedemikian dilihat sebagai suatu ancaman keamanan bagi Israel.

95 "Warga Palestina dilarang mendapat warga Israel", laman sesawang $B B C$ Indonesia, dikemaskini 12 Januari 2012, dicapai 1 Februari 2018, http://www.bbc.com/indonesia/dunia /2012/01/12011 2_palestine _israel

96 Nā'ilah Hāshim Șabrī (Pengarang al-Mubșir li Nūr al-Qur'ān), dalam temubual dengan pengkaji, di bilik 803 Hotel Impiana, Ipoh, Perak pada 11 Februari 2018, 2.45 petang (sempena lawatan beliau bersama suaminya ke Malaysia, dalam siri jelajah negara bagi pengisian program 'al-Quds Lanä' yang dianjurkan oleh pertubuhan Aman Palestin. 
Hal sedemikian berlaku, kerana mereka bakal menghadapi risiko terlucut identiti sebagai warga Palestin. Demi mengekalkan identiti mereka sebagai warganegara Palestin, para wanita Palestin membuat keputusan untuk terus istiqamah di wilayah-wilayah Palestin dan menjadi murabițāt yang sentiasa bersedia mempertahankan Masjid al-Aqsa dan Baitul Maqdis. ${ }^{97}$

\section{Peranan Murabițāt dan Jül al-Tahrīr (Generasi Pembebas)}

Berdasarkan fenomena hari ini yang memperlihatkan peningkatan kesedaran umat Islam untuk membela agama, Nā'ilah Hāshim Șabrī melihat perlunya satu tunjang kekuatan yang mampu mencetus kemenangan perjuangan Islam. Bagi beliau, tunjang kekuatan tersebut ialah bila adanya persiapan yang rapi dan persediaan yang lengkap serta teratur bagi menentang musuh Islam agar hak-hak kaum muslimin yang telah lama dirampas dapat dikembalikan. ${ }^{98}$

Justeru Nā'ilah melihat, para wanita muslimah mempunyai peranan yang besar dalam gerak kerja dakwah, kerana merekalah yang banyak membantu dalam membangunkan rumahtangga Islam yang menjadi tonggak utama dalam pembinaan daulah Islamiyyah. Ini kerana, para wanitalah yang bakal membentuk generasi muslim yang soleh, yang akan mewarisi amanah dalam meneruskan perjalanan dakwah dan jihad. ${ }^{99}$ Justeru beliau menegaskan, termasuk dalam ertikata persiapan tersebut ialah pembentukan $j \bar{l} l$ al-tahrìr, iaitu anak-anak generasi Islam yang dibentuk dan dipersiapkan dengan bekalan ilmu, akhlak mereka dibentuk dengan kesyumulan keperibadian yang tinggi serta semangat jihad mereka terus-menerus disuntik untuk menjadi mata rantai yang

97 Semangat al-ribāt demi mempertahankan al-Aqsa semakin meningkat dari hari ke hari dalam kalangan penduduk Islam Palestin termasuk kanak-kanak dan kaum wanita. Lihat Sabri, "Hum fĩ Rubāt-Shaykh 'Ikrimah Sabrì”, laman sesawang Youtube, di muatnaik pada 26 Februari 2018, dicapai pada 3 Mac 2018, https:// www. Youtube .com / watch?v=3Bjqp_-pGSk.

98 Nā'ilah, "Istirdād al-Huqūq al-Maslūbah dalam Khawātir Nadiyyah wa Afkār Maqdasiyyah, 358-359.

99 “Zaujah 'Ikrimah Șabrī Turșad Mu'ānah al-Mar'ah al-Maqdasiyyah”, laman sesawang Lajnah al-Quds, dikemaskini 1 April 2012, dicapai 5 Febuari 2012, http://www.alquds.gov. ps/ar/.?View=9YOcy0nNs3Du69 tjuhzy1wky eayxx\% 2B 7\%2FanzAhkX W eIT 9jMURkT. 
menyambung perjuangan dakwah menegakkan agama Allah di muka bumi. Inilah kefahaman yang cuba diterapkan oleh Nā'ilah dalam tafsiran ayat 60 surah al-Anfāl:

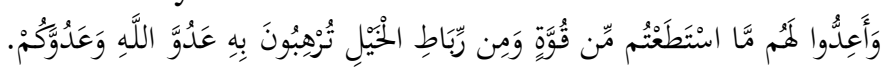

Al-Anfāl 8:60

Terjemahan: "Dan persiapkanlah untuk menentang mereka (musuh yang menceroboh) segala jenis kekuatan yang dapat kamu sediakan dan dari pasukan-pasukan berkuda yang lengkap sedia, dengan persediaan itu dapat menggerunkan musuh Allah dan musuh-musuh kamu."

Selain daripada usaha mewujudkan generasi pembebas tersebut, Lantaran itu, bagi Nā'ilah, semangat al-ribāt ${ }^{100} \mathrm{demi}$ mempertahankan al-Aqsa yang telah sedia ada dalam kalangan penduduk Palestin perlu disemarakkan lagi agar seluruh umat Islam, termasuk kanak-kanak dan kaum wanita turut bersama dalam memperjuangan membebaskan bumi Palestin.

Walaupun menyedari hakikat bahawa perjuangan tersebut bukan suatu perkara yang mudah untuk dicapai, Nā'ilah tetap istiqamah dalam membawa kaum wanita Palestin memainkan peranan sebagai murabițat. ${ }^{101}$ Bagi beliau, umat Islam perlu terus istiqamah dan sabar dalam melakukan ketaatan dan thabāt dalam perjuangan mempertahankan Islam. Inilah kefahaman yang telah diterjemahkan oleh Nā'ilah dalam usaha dakwahnya, berdasarkan perintah Allah yang dinyatakan dalam ayat 200 surah Āli 'Imrān ${ }^{102}$ :

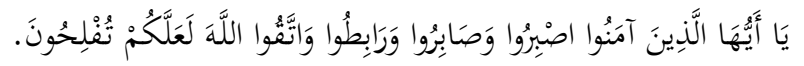

Āli ‘Imrān 3:200

Terjemahan: "Wahai orang-orang yang beriman, bersabarlah kamu (menghadapi segala kesukaran dalam mengerjakan kebaikan),dan kuatkanlah kesabaran kamu (lebih dari

${ }^{100}$ Lihat Șabrī, "Hum fì Ribāț- Shaykh 'Ikrimah Șabrī”, laman sesawang Youtube, di muatnaik pada 26 Februari 2018, dicapai pada 3 Mac 2018, https:// www. Youtube .com / watch?v=3B jqp_-pGSk.

${ }^{101}$ Dalam konteks dakwah semasa, murābițūn atau murābitāăt merujuk kepada kelompok petugas dalam satu gerakan dakwah yang tetap teguh dan sentiasa bersedia menginfaqkan diri mereka untuk menjalankankan kerja-kerja dakwah demi mendaulatkan agama Islam.

${ }^{102}$ Nā'ilah, al-Mubșir li Nūr al-Qur'ān, 2, juz 4: 178-180. 
kesabaran musuh di medan perjuangan) dan bersedialah (dengan kekuatan pertahanan di sempadan daerah) serta bertaqwalah kamu kepada Allah, mudah-mudahan kamu berjaya (mencapai kemenangan)".

Menerusi laungan slogan, "al-Quds Lanā"103 dan Labbayk yā Aqșā", Nā'ilah terus-menerus membakar semangat para murabițāt agar mereka sentiasa optimis dengan pertolongan Allah SWT dan kemenangan Islam. Walaupun dari semasa ke semasa pihak Zionis sentiasa meningkatkan sekatan dan halangan ke atas penduduk Palestin termasuk para wanita bagi menghalang mereka memasuki Masjid al-Aqsa. ${ }^{104}$ Atas semangat al-ribāt demi mempertahankan al-Aqsa, ia terus-menerus membakar semangat juang anak-anak Palestin yang semakin berani bersemuka dengan askar-askar Zionis Israel. ${ }^{105}$ Antara lontaran semangat yang dapat dilihat ialah melalui sedutan ucapan beliau:

"Aku menyeru kepada setiap wanita muslimah agar mendidik anak-anak anda dengan tarbiyyah Islamiyyah yang betul, supaya hasil tarbiah tersebut akan hidup dalam diri anak-anak lalu mereka menjadi pendukung kepada isu-isu Palestin dan mereka cintakannya lalu mereka akan nampak sejarah Islam kita. Ceritakan kepada mereka, kisah-kisah Saidina 'Umar alKhaț̣āa dan Șalaḥ al-Dīn al-Ayyūbī, dan begitu banyaknya kubur para Sahabat di sini. Ceritakan kepada mereka

103 Nā'ilah Hāshim Șabrī, "Jam ‘iyyah Nisā' al-Islām” (Laporan Tahunan, Persatuan Wanita Islam al-Quds, Jerusalem, 2000), 51-53.

${ }^{104}$ Berdasarkan statistik yang dikeluarkan oleh Jabatan Kajian dan Informasi, Muassasah al-Quds al-Duwaliyyah (bagi tahun 2015 sahaja) pihak Zionis Yahudi telah menyenaraikan seramai 60 orang wanita dalam kalangan murābițăt yang termasuk dalam 'senarai hitam' individu yang dihalang dari memasuki Masjid al-Aqsa. Lihat Barā'ah Darzī dan 'Alī 'Ibrahīm, "Ḥāl alQuds 2015 Qirā'ah fì Masār al-'Aḥdāth wa al-Ma'ālāt” (Laporan Tahunan alQuds 2015, Jabatan Kajian dan Informasi, Muassasah al-Quds al-Duwaliyyah, 2016), 9.

${ }^{105}$ Nā'ilah Hāshim Șabrī (Pengarang al-Mubșir li Nūr al-Qur'ān), dalam temubual dengan pengkaji, di bilik 803 Hotel Impiana, Ipoh, Perak pada 11 Februari 2018, 2.45 petang (sempena lawatan beliau bersama suaminya ke Malaysia, dalam siri jelajah negara bagi pengisian program 'al-Quds Lanā' yang dianjurkan oleh pertubuhan Aman Palestin 
kelebihan Baitul Maqdis sebagai tempat Isra' dan Mi'raj baginda Rasulullah SAW". ${ }^{106}$

Pada peringkat awal misi dakwahnya, Nā'ilah berjaya mengajak sebahagian dari kaum wanita di Baitul Maqdis untuk membawa anak-anak mereka menghadiri sama kuliah pengajian agama yang diadakan di perkarangan Masjid al-Aqsa. Bagi Nā'ilah Hāshim Șabrī, tindakan beliau yang sedemikian adalah bermatlamatkan serampang dua mata. Pertamanya, setiap hari akan ada dalam kalangan para wanita yang tetap mengunjungi Masjid al-Aqsa, walaupun kadang-kadang terpaksa mendirikan solat hanya di perkarangan Masjid al-Aqsa. ${ }^{107}$ Kedua, bertujuan untuk membiasakan anak-anak Islam mendengar bacaan ayat-ayat al-Quran beserta tafsirannya.

Secara optimis, Nā'ilah yakin, natijah daripada kehadiran anak-anak watan Palestin ke Masjid al-Aqsa, nescaya akan tumbuh dalam jiwa suci anak-anak tersebut jati diri "Jîl alTahrīr" (Generasi Pembebas), ${ }^{108}$ yang sayangkan bumi suci Baitul Maqdis dan Masjid al-Aqsa, sekaligus membangkitkan semangat juang yang tinggi agar tidak gentar melawan musuh yang telah merampas tanahair mereka dan mencabul kesucian Masjid alAqsa. Bagi Nā'ilah, walaupun semakin hari tekanan pihak Zionis Yahudi ke atas penduduk Islam Palestin semakin meningkat, Nā'ilah Hāshim Șabrī tetap teguh menanam semangat para murabitāt Palestin untuk terus thabāt dan istiqamah dalam perjuangan. Ia dilihat cukup penting, kerana perjuangan tersebut memerlukan pewaris generasi yang akan menyambung perjuangan

106 “Zaujah 'Ikrimah Șabrī Turșad Mu'ānah al-Mar'ah al-Maqdasiyyah”, laman sesawang Lajnah al-Quds, dikemaskini 1 April 2012, dicapai 5 Febuari 2012, http://www.alquds.gov.p s/ar/?view=79YOcy0nNs3Du 69tjuhzy1 wkyea yxx \%2B7\%2FAnzy AHkXWeIT9jMURkT

107 Terdapat 15 buah pintu yang boleh digunakan untuk masuk ke dalam Masjid al-Aqsa. Walau bagaimanapun, hanya 10 buah daripada pintu-pintu tersebut yang dibuka untuk penduduk Palestin, manakala lima buah pintu yang lain ditutup dan dikawal ketat oleh tentera Zionis. Lihat Aḥmad Muhammad Yāsīn, "al-Ta'rīf bi al-Masjid al-Aqsā" (Jerusalem: Dār al-Risālah alMaqdasiyyah, 2011) 19.

${ }^{108}$ Lihat "Zaujah 'Ikrimah Șabrī Turșad Mu'ānah al-Mar'ah al-Maqdasiyyah", laman sesawang Lajnah al-Quds, dikemaskini 1 April 2012, dicapai 5 Febuari 2012, http:// www. alquds. gov.ps/ar/?view=79Y Ocy0nNs3Du 69tjuhz y1wkyeayxx\%2B7\%2FanzyAHkXWe IT9 jMU kT. 
tersebut dengan sepenuh keyakinan kepada janji-janji Allah, dan tidak sesekali gentar berhadapan dengan musuh kuffār. Bagi Nā'ilah, itulah cara yang sepatutnya dilakukan oleh seorang ibu yang mendidik anak-anaknya pengertian jihad dan pengorbanan yang sebenarnya. ${ }^{109}$ Sandaran hujah Nā'ilah ini dapat dilihat pada pentafsiran beliau surah Muhammad ayat $7::^{110}$

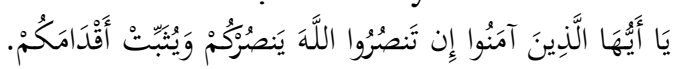

Muhammad 47:7

Terjemahan: "Wahai orang-orang yang beriman,kalau kamu menolong (agama) Allah, nescaya Allah menolong kamu (untuk mencapai kemenangan) dan meneguhkan tapak pendirian kamu"

Dalam hal ini, dapat dilihat secara jelas bahawa apa yang diterjemahkan dari pemikiran Nā'ilah, dalam usahanya mengajak kaum wanita Palestin untuk berperanan sebagai murabițat, telah memberi impak yang cukup besar kepada masyarakat Islam di Palestin khususnya. Walaupun terpaksa menghadapi pelbagai ancaman dan tekanan ${ }^{111}$ dari pihak Zionis Yahudi, namun ia tidak melemahkan semangat "al-Dā'iyah al-Maqdasiyyah" untuk bersama-sama dengan para murabițāt yang menjadi tonggak kepada kelangsungan generasi pembebas bumi Palestin.

\section{Penutup}

Paduan daripada garapan pemikiran politik Nā'ilah dan ketokohan beliau sebagai seorang mufassir cukup terserlah menerusi

109 “Zaujah 'Ikrimah Șabrī Turșad Mu'ānah al-Mar'ah al-Maqdasiyyah”, laman sesawang Lajnah al-Quds, dikemaskini 1 April 2012, dicapai 5 Febuari 2012, http://www.alquds.gov.ps/ar/?view=79YOcy0nNs3Du69 tjuhzy1wkyeayxx $\% 2 B 7 \% 2 F A n z y$ AHkXWeIT9jMURkT

${ }^{110}$ Nā'ilah, al-Mubșir li Nūr al-Qur'ān, 10, juz 26 : 61-62.

111 Peritiwa penutupan Masjid Al-Aqsa pada 14 Julai 2017, antara peristiwa yang banyak memberi kesan kepada Nā'ilah, apabila suaminya sendiri iaitu 'Ikrimah Șabrī, turut tercedera dalam serangan mengejut yang dilakukan oleh pihak Zionis Yahudi. Namun, rentetan dari peristiwa tersebut, lebih ramai para pemuda pemudi Islam Palestin berhimpun dengan teguh bersama para ulama menjadi kalangan al-ribāt (termasuk para murabițāt) yang mempertahankan Masjid-Aqsa. Lihat "Hum fī Ribāț-Shaykh 'Ikrimah Șabrî̀", laman sesawang Youtube, dimuatnaik pada 26 Februari 2018, dicapai pada 3 Mac 2018, https://www.Youtube.com/watch?v=3Bjqp_-pGSk.https://youtu .be/Zgr UFNW04EY 
pentafsiran beliau dalam perbincangan ayat-ayat al-Quran yang menyentuh secara lansung tentang sejarah bumi Palestin dan Masjid al-Aqsa. Ia dapat dilihat secara jelas dan konsisten dalam penghuraiannya secara pragmatik dalam tafsir al-Mubșir li Nūr alQurān. Apa yang dapat dirumuskan ialah, fokus utama yang diberi penekanan oleh Nā'ilah $\overline{1}$ ialah bagi mengangkat persoalan isu Palestin sebagai isu umat Islam sejagat. Justeru, hal sedemikian telah berjaya meletakkan nama Nā'ilah sebagai personaliti dakwah dan ikon mufassir wanita yang mempunyai sumbangan yang signifikan dalam bidang tafsir.

\section{Rujukan}

'Ammārah, Muhammad. Al-Quds Bayna al-Yahūdiyyah wa alIslām (Kaherah: Dār Nahḍah Miṣr li al-Ṭibā'ah wa al-Nashr wa al-Tawzī', 1999.

Al-Alūsī, Maḥmūd bin 'Abd Allāh al-Ḥusaynī. Ruḥ al-Ma 'ānī fì Tafsìr al-Qur'ān al- 'Az̄ìm wa al-Sab'u al-Mathān. Beirut: Dār al-Fikr, 1994.

Al-Dhahabī. Kisah 'Isrā'îliyyāt dalam Tafsir dan Hadith. terj. Ahmad Fadilah Sarnap. Johor Bharu: Perniagaan Jahabersa, 1996.

Al-Ghazzālī. Muḥammad. Al-Yahūd al-Mu'tadun wa Dawlatuhum Isrā'ìl. Damsyik: Dār al-Qalam, 1999.

Al-Khalaf, Sa'ūd bin 'Abd al-'Azīz. Dirāsāt fì al-Adyān alYahūdiyyah wa al-Nașrāniyyah. Riyadh: Aḍwā’ al-Salaf, 2006.

Al-Khālidī. Șalāḥ 'Abd al-Fattāḥ. 'Isrā'iliyyāt Mu'āṣarah. Amman: Dār 'Ammār, 1997.

Al-Khālid̄̄. Șalāḥ 'Abd al-Fattāḥ. Al-Syakhsiyyāt al-Yahūdiyyah min Khilāl al-Qur'ān Damascus: Dār al-Qalam, t.t.

Al-Khālidī. Șalāḥ 'Abd al-Fattāḥ. Taṣwībāt fi Fahm Ba'ḍ al-Āyāt. Damsyik: Dār al-Qalam, 1995

Al-Ṭabarī, Abū Ja'far Muhammad bin Jārīr bin Yazīd. Jāmi ‘ alBayān 'An Ta'wīl Āyi al-Qur'ān. Beirut: Dār al-Fikr, 1988.

Al-Zuhaylī. Wahbah. Tafsīr al-Munīr fi al- 'Aqīdah wa al-Sharī'ah wa al-Manhaj. Beirut: Dār al-Fikr al-Mu'āșir, 1991.

Ibn Kathīr, 'Ismā'īl bin 'Amr bin Kathīr. Qișaș al-Anbiyā'. Tahqū̄ Qāsim al-Rifā'ì. T.tp.: Sharikah Dār al-Arqām bin Abī alArqām, t.t. 
Ibn Kathīr, 'Ismā‘īl bin 'Amr bin Kathīr. Tafsīr al-Qur'an al'Azim. Beirut: Dār Ibn Hazim, 2000.

Laman sesawang BBC Indonesia, "Warga Palestina dilarang mendapat warga Israel", dikemaskini 12 Januari 2012, dicapai 1 Februari 2018, http://www.bbc.com/indonesia/dunia /2012/01/12011 2_palestine _israel

Laman sesawang al-Jazeera, "Al-Qaraḍāwī Yuharrim Mujaddadan Ziyārah al-Quds", dikemaskini 13 Julai 2010, dicapai 25 April 2018, http://www. aljazeera. net/ news/arabic/2010/7/13/\%D8\%A7\%D9\%84\%D9\%82\%D8\%B1 $\% \mathrm{D} 8 \% \mathrm{~B} 6 \% \mathrm{D} 8$.

Laman sesawang Fair Observer, "Palestine and International Law", dikemaskini 21 September 2011, dicapai 3 Mac 2018, https://www.fairobservercom/ region/middle_east_north_africa/palestine-and-internationallaw/.

Laman sesawang Wikipedia al-Mawsü'ah al-Hurrah, "Ikrimah Șabrī”, dicapai 7 Januari 2013, http://ar.wikipedia.org/wiki/\%D8\%B9\%D9\%83\% D8\%B1\% D9\%85\%D8\%A9_\%D8\%B5\%D8\%A8\%D8\%B1\%D9\%8A.

Laman sesawang YouTube, "Al-Qaraḍāwī: Ziyārah al-Quds li Ghayr al-Palasținniyyīn Haram Shar'an",dikemaskini 17 Jun 2012, dicapai 25 April 2018, https:// www. youtube.com/watch?v=bGkiJyUQdOU.

Laman sesawang Youtube, "Hum fī Rubāt-Shaykh 'Ikrimah Șabrī”, dikemas kini pada 26 Februari 2018, dicapai pada 3 Mac 2018, https:// www. Youtube .com / watch?v=3Bjqp_-pGSk.

Mohamad Fauzi bin Zakaria. "Bumi Yang Dijanjikan Menurut Perspektif Yahudi dan Kaitannya dengan Penubuhan Negara Israel (1948): Analisis dari Sudut Perspektif Islam". Tesis kedoktoran, Jabatan Akidah dan Pemikiran Islam, Universiti Malaya, Kuala Lumpur, 2011.

Mohd Roslan Mohd Nor. "Konflik Israel -Palestin dari Aspek Sejarah Moden dan Langkah Pembebasan dari Cengkaman Zionis". Jurnal Al-Tamaddun 5. Kuala Lumpur: Akademi pengajian Islam Universiti Malaya, 2010.

Mohd Roslan Mohd Nor. "Perancangan Zionis $\mathrm{Ke}$ Arah Pembentukan Negara Israel". Jurnal Usuluddin 30 (JulaiDisember 2009). 
Șabrī, 'Ikrimah Sa'īd. Fatāwā Maqdasiyyah. Amman: Dār al-Nur al-Mubīn li al-Dirāsāt wa al-Nashr. 2011.

Șabrī, 'Ikrimah Sa'īd. Haqqunā fì Falasțīn. Amman: Dār alNafâ'is, 2010.

Șabrī, Nā'ilah Hāshim. Al-Mubșir li Nūr al-Qur'ān. Amman: Maṭba'ah al- Risāalah al-Maqdasiyyah, 2003.

Șabrī, Nā'ilah Hāshim. F̄̄ Zilāl Āyah. Amman: Dār al-Nafā'is, 2014

Șabrī, Nā'ilah Hāshim. Hadhihi Ummat̄̄ (Jerusalem: Maṭba'ah Dār al-'Aytām al- 'Islamiyyah al-Șinā'iyyah bi al-Quds, 1980

Șabrī, Nā'ilah Hāshim. Kawākib al-Nisā'. Cet. ke-2, Al-Quds: Dār al-Risālah, 2007.

Șabrī, Nā'ilah Hāshim. Khawāțir Nadiyyah wa Afkār Maqdasiyyah. Amman: Dār al-Nafā'is, 2014.

Șabrī, Nā'ilah Hāshim. Palesținiyyyah Sa'abqā. Jerusalem: Maṭba'ah Dār al-'Aytām al-'Islāmiyyah al-Șinā'iyyah bi alQuds. t.t.

Șabrī, Nā'ilah Hāshim. Wamḍh fì Zulām. Jerusalem: Mațābi‘ alQuds al-'Arabiyyah, 1978.

Yūsuf al-Qarḍāwī. Al-Aqsa Tanah Wakaf Umat Islam: Khuṭbah al-Shaykh Yūsuf al-Qaraḍ̄wwī Nafahāt al-Jum'ah, terj. Arsil Ibrahim. Kuala Lumpur: Ana Muslim Sdn.Bhd, 2014.

Yūsuf al-Qarḍāwī. Thaqafah al-Dā'iyah. Beirut: Mu'assasah alRisālah, 1978.

Zulkifli Hj Mohd Yusoff. Pelita untuk al-Aqsa; Risalah Pada Menjelaskan Kedudukan Masjid al-Aqsa dan Kewajipan Membelanya. Kuala Lumpur: Al-Quds Foundation Malaysia, 2017.

\section{Temu Bual}

'Ammār Șabrī (anak sulung Nā'ilah Hāshim Șabrī), dalam temubual dengan pengkaji, di Bilik 2612, PNB Perdana Hotel \& Suites, 10 Jalan Binjai, Kuala Lumpur pada 2 November 2017, 2:30 petang.

'Ikrimah Sa'̄id Șabrī (suami Nā'ilah Hāshim Șabrī), dalam temubual dengan pengkaji, di Bilik 2612, PNB Perdana Hotel \& Suites, 10 Jalan Binjai, 50450 Kuala Lumpur, 2 November 2017, jam 2.30 petang. 
Nā'ilah Hāshim Șabrī (Pengarang karya al-Mubșir li Nūr alQur'ān), dalam temubual dengan pengkaji, di rumah beliau di Peti Surat 17412, Hayy al-Șawānah, al-Ṭūr, 97500 Baitul Maqdis, Palestin pada 21 November 2012, 8.30 malam.

Nā'ilah Hāshim Șabrī, dalam temubual dengan pengkaji, di Bilik 1002, Grand Cevahir Hotel Convention Center, Istanbul, Turki, pada 4 November 2018 jam 9.00 pagi.

Nā'ilah Hāshim Șabrī, dalam temubual dengan pengkaji, di Bilik 2612, PNB Perdana Hotel \& Suites, 10 Jalan Binjai, Kuala Lumpur pada 2 November 2017, 2:30 petang.

Nā'ilah Hāshim Șabrī, dalam temubual dengan pengkaji, di Bilik 3005, PNB Perdana Hotel \& Suites, 10 Jalan Binjai, Kuala Lumpur, pada 21 Oktober 2018 jam 10.30 pagi.

Nā'ilah Hāshim Șabrī, dalam temubual dengan pengkaji, di bilik 803 Hotel Impiana, Ipoh, Perak pada 11 Februari 2018, 2.45 petang. 